This document is published in:

Economic History of Developing Regions,2013. 28:1, 28-68, DOI: $\underline{10.1080 / 20780389.2013 .805508}$

(c) Taylor \& Francis (Routledge) 


\title{
ON THE ACCURACY OF EXPORT GROWTH IN ARGENTINA, 1870-1913
}

\author{
Antonio Tena-Junguito and Henry Willebald ${ }^{1}$
}

\section{ABSTRACT}

Argentine export growth before the First World War is considered one of the most relevant variables in order to understand the main characteristics of Argentina's long-run modern economic growth properly. The lack of accuracy of the official export series, especially the relative official values used, lies behind some of the controversies and doubts of the historiography when addressing the causes and consequences of Argentina's international convergence. We have used empirical evidence to test the accuracy of quantities and value exports records, first, according to their import partners' records and, second, according to international market prices. Results show that the hypothesis of export price undervaluation bias is correct. In the light of these results we reconstructed a new Argentine export f.o.b. values and price index using international prices valued in pounds sterling which allows us to offer a new proposal indicating a more dynamic Argentine export growth during the Belle Époque years.

Keywords: Latin America, first globalisation, Argentina, exports growth, accuracy exports

JEL classification: F14, N76

\section{INTRODUCTION}

In the third quarter of the 19th century, according to most studies, Argentine living standards were higher than most Latin American countries, but closer to the European periphery than to the rich European or new settler countries (Australia, New Zealand and the United States). By the early 20th century,

1 Antonio Tena-Junguito, Associate Professor Departamento de Historia Económica and Research Fellow Instituto Figuerola Universidad Carlos III de Madrid. Email: antonio.tena@uc3m.es; Henry Willebald, Faculty member Instituto de Economía de la Universidad de la Republica, Uruguay, and Associate Research Fellow Instituto Figuerola Universidad Carlos III de Madrid. Email: hwillebald@iecon.ccee.edu.uy. 
Argentina had become a member of the exclusive club of the top ten richest countries in the world. As a temperate land-abundant country far from Europe's industrial centres, Argentina benefited from the international specialization produced by the transport revolution in bulky primary commodities. Argentina became part of the global economy in the last quarter of the 19th century largely as the result of the export of a small range of primary products along with the attraction of external labour and capital flows. The favourable conditions of this international expansion during the Belle Époque were apparently interrupted by the First World War and its aftermath. ${ }^{2}$ Notably, Argentina had fiscal and monetary problems produced by the overexposure of the British Baring Bank to Argentine and Uruguayan public and private debt in the late 1880s. The Argentine economy did not really enjoy a stable monetary framework after the major default produced by the Baring crash in the early 1890s (Della Paollera and Taylor 2001). In the end, The Bank of England rescue prevented what could have been a worldwide financial collapse. The financial crisis produced a monetary depreciation and slowed down the entrance of new capital, reducing investment and altering GDP growth, but we do not have a clear idea of exactly how much both situations affected Argentinean export performance (Regalsky, 1986, 2002).

Argentine export growth before the First World War is considered one of the most important variables in explaining the characteristics of Argentina's long-run modern economic growth. Primary products led this international boom, but the historiography has yet to agree about the level and speed of this export growth experience, the impact of the Baring crisis and the relative prominence of the role of cattle and crop commodities during the period. The lack of accuracy of the official export series, especially the relative official values used, lies behind some of the controversies and doubts within the historiography.

Most specialists in this period have used partial statistics for the volume of commodity exports in their analysis of Argentine expansion during the years 1870 to 1913 because they did not trust the country's official export figures for the period. Examples of this approach include Diaz Alejandro (1970), Di Tella and Zymelman (1967), Cortes Conde (1979), Rapaport (1990), Vazquez-Presedo

2 The assessment that Argentine retardation began after 1913 depends entirely on the basis of comparison. On the one hand, if we compare with Australia and Canada, performance during the interwar years is respectable (as noted by Taylor 1992). This point of view is also shared by Diaz Alejandro (1970, 51-5), who thinks that Argentina converged upwards to Australian levels in the 1920s even if the new settler countries retarded relative to the OECD in the interwar years. On the other hand, Di Tella and Zymelman (1967) and more recently Della Paolera and Taylor (2003) or the econometrics work offered by Sanz (2004), focus their attention on the Argentine structural break in GDP growth trends produced by the First World War and the retardation produced by the Argentine policies in the aftermath years. 
(1971a, 1971b). ${ }^{3}$ It is remarkable that nobody, with the exception of Dieguez (1972), used the important efforts made by a group of well-known Argentinean economic historians in the 1960s - we refer in particular to the analysis of Cortes Conde, Halperin and Gorostegu 1965 - to revaluate the official export statistics and to offer a new current and constant export series. ${ }^{4}$ In this study official values ("valores nominales") were corrected by estimating domestic market values ("valores reales"), tracing backwards the work done by the Dirección General de Aduanas from 1910 onwards. ${ }^{5}$ No consensus about the accuracy of these revaluations was reached and no other serious attempt to follow a similar approach has been made in the last 40 years. ${ }^{6}$

The objectives of this paper are firstly to challenge the uncritical acceptance of the official Argentinean export figures since the work of Cortes Conde, Halperin, and Gorostegui de Torres (1965). Secondly, this paper offers a methodological alternative to the Cortes Conde, Halperin, and Gorostegui de Torres approach (see Dieguez 1972). Our results are, in general, quite similar to the Cortes Conde work except for the Baring crisis years and its aftermath. They accepted that during the 1890s and afterwards, undervalued official export crop values were representative of market prices. We do not accept this. Other minor differences in our results are probably the result of minor methodological differences in revaluation (our international prices in pounds versus their domestic market prices in current pesos).

3 The most well-known contemporaneous studies of Argentine trade statistics, such as Latzina (1905) or Tornquist (1919), are also critical of the accuracy of the statistics but do not make any effort to re-evaluate official values. Only Bunge (1918), as discussed below, presented a serious study in this direction for the years 1910-1916 preceding the official works of revaluation made by the Dirección General de Estadística Argentina.

4 The work of Cortes Conde, Halperin, and Gorostegui de Torres (1965) is available as a restricted monograph but it has never been published even though it is well-known by Argentine economic historians. As quoted in this monograph: "El trabajo completo con las series anuales se encuentra en vías de publicación; hoy solo presentamos, a modo de muestra, los resúmenes y plantillas detalladas de los años 1864-1871-1880-1890-1900-1910-1920 1930-1940-1950-1960-1963 (see Cortes Conde, Halperin, and Gorostegui de Torres, 1965, p. 3).

5 From 1910 onwards official values (valores nominales) have been commuted by yearly estimated domestic market values (valores reales). The last records were also called "valores de plaza" and were f.o.b. prices estimated yearly by the Dirección General de Estadística Argentina according to periodical observations of domestic market prices, see DGE (1937) p. XXIIIXXIV. The new export series elaborated by Cortes Conde, Halperin, and Gorostegui de Torres (1965), for the years 1864-1963, follows a similar methodology to the DGE using domestic market prices (valores de plaza). These results differ from the official export figures by an annual average of $15.6 \%$ during the period 1864 to 1899 (see Dieguez, 1972, note 2, p. 335).

6 Surprisingly, no national or international publications pay attention to the proposal made by Cortes Conde, Halperin, and Gorostegui De Torres (1965). See Ferreres (2005) or Mitchell (2007), where both assume implicitly that failings in the reliability of the Argentine official export figures are not so serious and present the official export series without even mentioning the existence of problems in their accuracy. 
Our results finally offer a new current and a constant price export series, both valued in sterling pounds. This new profile shows how Argentine export-growth acceleration began in the early 1890s and was sustained during the Baring crisis. The period was marked by the contrasting influences of financial instability and monetary depreciation on the one hand, and a sustained increase in the international demand for primary products on the other. At the same time this period witnessed the end of frontier expansion in Argentina. This stimulated the intensity of production of some crops through the increasing use of artificial pastures. Overall our results show how the financing problems during the Baring crisis acted negatively, mainly on cattle. This negative effect was not so great on crop exports, though. These exports provided an earlier and more consistent growth performance for Argentina during the Belle Époque years than was previously thought. ${ }^{7}$

\section{ON THE POLITICAL ECONOMY OF ARGENTINA'S OFFICIAL EXPORT VALUES}

Argentine historical trade records were compiled both for fiscal and statistical information purposes. Nevertheless, in the case of exports (which were usually taxed at lower rates than imports and so had lower incentives for contraband), the literature trusts the records of quantities. This is not the case with official values which the literature assumes were estimated more for fiscal reasons than for statistical purposes and, therefore, frequently failed to reflect market price trends. The discussion in the literature of the bias in Argentina's export series fits this hypothesis based on the existence of a general undervaluation. Were these undervaluations a result of the pressure exerted by cattle exporters lobbies to pressure reduce their taxes, or were they a consequence of the lack of incentives to update official values on a yearly basis, which would have affected the official values of both the crop and the cattle numbers? ${ }^{8}$ We seek to provide an answer to this important question.

Official Argentine publications recognize that the most remarkable bias in the export series came from the use of official valuation and differences with respective international market prices. Exports were taxed at lower rates than imports but used the same system of official valuation called "tarifa de avalúos". From the first published trade statistics in the Anuario del Comercio Exterior in 1864 and, in some cases until 1916, the official statistics used official values

7 See Cortes Conde (1979) pp. 90-91, but also Diaz Alejandro (1970); Di Tella and Zymelman (1967); Cortes Conde (1990); Rapaport (1990); Vazquez-Presedo (1971a, 1971b).

8 The undervaluation hypothesis is discussed by official contemporary statistics and by economic historians. See, respectively, the introduction of Dirección General de Estadistica. Argentina (1913), and Cortes Conde, Halperin, and Gorostegui de Torres (1965). 
(mentioned in different ways as "valores de aforo", "valores de avalúos" or "valores de tarifa) which were not modified to keep step with market prices. ${ }^{9}$

Official export tariffs were specific, that is, they were paid based on the volume exported (see Latzina 1905, 4). However, they were normally estimated and published "ad valorem" until 1906, when export taxes were abolished. This means that exporters preferred official values to be undervalued in order to appear to be paying more tax than they really were. For the same reason the administration was interested in the opposite situation but traditional export sector lobbies apparently had influence on the commission in charge of the publication of the tables of official values (comisión de aforos). Cortes Conde, Halperin, and Gorostegui de Torres (1965) suggested, following this argument, that some traditional goods like the "cattle products" in Argentina's exports in the 1870s and 1880s such as skins, wool, tallow and salted meat, were probably more undervalued than the "crop products" such as wheat, maize, linseed and flour. According to this work, from 1892 onward the pressure of tariffs on cattle exports moderated significantly and some efforts were made to reduce the distance between the table of official values (valores de aforo) and domestic market prices (valores de plaza) This situation would improve further after 1906 when export taxes were abolished. Official values were modified to domestic market prices by A. E. Bunge (1918) for the years 1910-16 before Argentine trade statistics incorporated new annual estimations of domestic market prices. Both estimations have been introduced as official values in export statistics in most of the official retrospective trade publications from 1931 onwards and will be included in our study as part of the official export series to be tested for the years 1910-13. ${ }^{10}$

As mentioned above, a serious attempt at correction of the official Argentine export figures for the years 1864-1916 was made by Cortes Conde, Halperin, and Gorostegui de Torres (1965). The correction assumed that the quantities were accurate and is based on the revaluation of the official values of 15 different export products for domestic prices. ${ }^{11}$ The proposal is limited to some specific years because, according to the interpretation of the authors, yearly domestic

9 In 1880 the value of taxed exports was ten times those not taxed (50.8 against 5.6 million pesos), see Anuario 1880 p. XVIII. The official publication "Estadistica del Comercio Exterior 1880 ", p. 17, recognizes that these "valores de tarifa" were the main reason for the existence of a low quality trade statistic: "De aqui se siga que nuestra estadística comercial revista en cuanto a sus valores, cierto carácter de ficticio... Nuestra actual legislación aduanera es, pues, enemiga de una buena estadística. Quoted in Corte Conde, Halperin, and Gorostegui de Torres (1965, 36-7).

10 From 1931 onwards Argentina's official trade publications are called "Anuario del Comercio Exterior de la República Argentina correspondiente al año. . y noticia sumaria del periodo 1910 a...".

11 Domestic prices were obtained from Boletín de la Bolsa de Comercio and Boletín de la Bolsa de Cereales and other national journals. The exception would be "carne congelada" (frozen beef), an increasingly important export product from 1885 to 1913 . These unitary values were UK c.i.f. import values taken from the journal The Economist. They translate c.i.f. values to f.o.b. 
prices were introduced from 1892 onwards for most agricultural commodities (wheat, maize, linseed, flour). So, for these products, revaluation is only proposed for the years 1864-91. For cattle commodities such as raw wool, skins, tallow and salted meat, the official values after 1906 were trusted; and for animals, frozen mutton, chilled and frozen beef meat the official values were not trusted until 1916.

Cortes Conde, Halperin, and Gorostegui de Torres (1965) decided to accept official values for crop commodities throughout the period and this is our main disagreement with their seminal work. Evidence shows that neither official crop values nor cattle commodities were updated yearly. So prudence suggests that it would be better not to exclude crop products from the sample of products to be tested and corrected with market prices. In addition, we question below if the best way to correct the official values should be based mainly on domestic market prices. Export commodities were sold according to their quality at international market prices. Many reasons, such as the small dimension of the domestic market, the distortion produced by protection or the different qualities of the products sold on the domestic market in comparison with the international market, leads us to suspect that domestic market prices may be biased in relation to international prices. Furthermore, to compare official values with domestic prices, it is also necessary to introduce controversial decisions about conversion rates from gold pesos to current pesos (pesos oro to pesos papel). These rates have long been subject to debate and, in consequence, represent a potential additional bias. ${ }^{12}$

Before 1881, the monetary unit used in Argentine national statistics is the "peso fuerte" which is very close to the "peso oro" used from that year to 1930. What is more important, however, following Cortes Conde, Halperin, and Gorostegui de Torres (1965, 47-53), we assume that Argentine international trade transactions took place in "pesos oro" between 1881 to 1930 and in "pesos fuertes" before that year. To solve the problem of homogenization before and after 1881, and taking advantage of the fact that we use British prices, we will measure Argentine exports in pounds sterling for the whole period. ${ }^{13}$

with a fixed coefficient estimated as 20 per cent for the whole period. This fixed percentage introduces an additional bias because technological changes in transport refrigeration meant major changes in the freight factor of beef from 35-40 per cent in the 1880 s to 10 per cent before the First World War (see notes on freight factor estimation in Appendix 3).

12 There is no agreement about the continuity between conversion rates of the "peso fuerte" and "peso oro" or even concerning the conversion of both to a common monetary unit such as the "peso papel". The most widely accepted exchange rate is that of Alvarez (1929), 115-20, but some recent works, such as Ferreres (2005), use other alternatives. Cortes Conde, Halperin, and Gorostegui De Torres (1965, 48-50), notice that the most important commodities exported were valued in gold but some products were valued in local silver currency.

13 Our estimation is measured in pounds sterling but it will be compared with the official figures, the Cortes Conde, Halperin, and Gorostegui de Torres (1965) data and the Corte Conde (1994) and Della Paolera and Taylor (2003) GDP figures (for the export/GDP ratio in Figure 10) using the 


\section{A DOUBLE TEST OF THE ACCURACY OF ARGENTINE EXPORT FIGURES}

As mentioned in the introduction, a double test of official Argentine export statistics is used in order to obtain more robust results concerning the trends and causes of their accuracy problems. We will use, first, the partners' records to test the potential bias of both quantities and prices taking into consideration problems of comparability between bilateral trade statistics caused by transit and different coverage. Second, we will test official values bias using international prices of commodities. The reason for using both tests is to check the hypothesis of the official value bias with two independent tests in order to improve the reliability of the final methodology used in the reconstruction of a new series.

\subsection{The partner records' accuracy index}

This paper takes advantage of the singularity of international trade statistics in that they offer a double independent record of the same economic transaction. It is well known that geographical assignment is usually the most problematic and unreliable part of the international trade statistics. However, import records are usually more reliable than geographical export assignment records. Bilateral import duty discrimination at the border means that officials are more interested in the geographical origin of imports than in the destinations of exports. Following studies by Federico and Tena (1991), Tena (1992), and Carreras and Badía (2008), we defend the comparison of trade records as a sound methodology to test the accuracy of values and quantities at the same time, and especially as a good complement to confirm the price bias revaluation profile in the case of problems with the quantities records. We are aware of the fact that this methodology has problems when used for statistical correction because one should take into account the traditional distortions created by transit trade across entrepôts, differences in trade partners' coverage records, such as the well-known classification of "comercio a órdenes" and, of course, the differences in c.i.f.-f.o.b. valuations in partners' records. However, we introduce proper corrections to moderate these limitations. ${ }^{14}$

cross exchange rate between pounds- peso fuerte-peso papel. For the peso fuerte-peso papel we use the estimation of Alvarez (1929, 122-3), offered by Dieguez (1972, 346). Between 1863 and 1875, the official exchange rate between the peso fuerte and the pound sterling was 4.9 and from 1876 to 1881 it was 4.88. The peso oro had a fixed exchange rate of 5.00 from 1882 to 1914 .

14 It should also be noted that in the Argentine case geographical export distribution was especially contaminated by "comercio a órdenes". The practice of shipping "for orders" was widespread in primary producer countries with high export concentrations in a few commodities and affected by price arbitrage fluctuations on the international market. The Argentine practice was to postpone the decision on how to record the destination of exports with the inclusion of a "comercio a órdenes" section in order to decide the final destination of 
For this test we use the import records of Argentina's main export trade partners before the First World War. These are mainly European countries and have some of the most highly respected statistics for unit values and "special trade" coverage accuracy through this period. This methodology accounts for prices and quantities and, in this case, it consists of comparing the total value of Argentina's official exports (according to its own statistics) with the sum of these flows as registered by its partner countries' records as imports.

We employ official bilateral data in current US dollars from official trade sources of European countries and the US ${ }^{15}$ and contrast the official export records of Argentina by countries with the imports of the same flows recorded by the official statistics of the United Kingdom, the United States, France, Germany, Belgium, the Netherlands, Italy and Spain. These countries account for around 80 to 90 per cent of the geographical distribution of Argentina's total exports during the period. We have also included the series of "comercio a órdenes" from 1895 to 1913 assuming that this series reproduces the same distribution as the rest of exports, so the data for this category is included, taking into consideration only the percentage that went to the group of our eight main trade partners each year. ${ }^{16}$

We employ the following equation:

$$
X A I_{i}=\frac{\sum_{j=1}^{N} X_{i j}}{\sum_{j=1}^{N} M_{i j}}
$$

Our "accuracy index" $\left(X A I_{i}\right)$ is the ratio of the total trade sum of Argentine exports to partner countries $\left(\Sigma X_{\mathrm{ij}}\right.$ where $\mathrm{i}$ represents Argentina and $\mathrm{j}$ the main trade partners) according to its statistics, including the aforementioned "comercio a

the products later, depending on the best offer contract at the port of destination. This practice in the official records was especially prevalent during the years 1895 and 1940 and "comercio $a$ órdenes" represented, as geographical destination records, between 25 and 35 per cent of total exports. It is well known that, at the end of the 1930s, statistical authorities made an estimation of the final geographical destination by trade partners included in this category. This estimation was published in several Anuarios Estadisticos Argentinos between 1927 and 1940. We have, therefore, been able to include a series of "comercio a órdenes" weighted with the rest of the geographical distribution of exports for the years 1895-1913; complete series of "comercio a órdenes" from 1895-1940 is offered by the Dirección General de Estadistica de la Nación (1958), p. XXI.

15 See Appendix 6.

16 We have preferred this neutral assumption to other riskier ones like that offered by Rayes (2010), Table C.5. Rayes takes into consideration the study of Ricardo Pillado published in the Anuario de la Dirección General de la Nación 1907, p. XXII, and extends the average of Pillado's estimation for the years 1901-05 to the whole period 1895-1913. Apparently estimations are made by correcting the geographical export records assigned in the "comercio a órdenes" according to the records of four important agricultural products (wheat, linseed, maize and quebracho wood) from the import records of their most important trade partners. 
órdenes" with that of the same flows according to the import records of Argentina's partner countries $\left(\Sigma \mathrm{M}_{\mathrm{ij}} j_{\text {th }}\right.$ country). This ratio includes a transportation cost component, i.e., the difference between the c.i.f. valuation of import records and the f.o.b. valuation of exports. The percentage of transportation cost and insurance (the so-called "freight factor") exported mainly to European countries usually depends more on the commodity composition of trade than on its geographical distribution. In the Argentine case we need transatlantic freight rates of the different Argentine export products to their main European destinations. Most of the freight rates we found for different products are yearly, and correspond to Buenos Aires or alternative nearby South American transatlantic routes. So our freight factor estimation is driven by the changes in the composition of products and the evolution of freight rates and product prices during the period not weighted by geographical destination. Appendix 3 describes the methodology and includes details of sources for individual products and the final results of the estimated freight factor of Argentine exports that goes from a minimum of 16 per cent to a maximum of 28 per cent, averaging 19 per cent for the period 1870-1913. In line with this, we do not offer freight adjustment for pairs of countries and only use the figure for the total export sum. Accuracy indexes for pairs of countries contrast Argentine export f.o.b. records with import c.i.f. records of their respective trade partners. So export f.o.b. records are not adjusted for the respective differences in freight factor, insurance and mercantile commission differences that import records include. This is the reason we present the Figure 1 with an interval from 80 (floor) to 100 (roof) (which would represent an average c.i.f.-f.o.b. ratio of 20 per cent). ${ }^{17}$ Results over or below this interval are considered to represent an over or undervaluation of the export series respectively.

As shown in Table 1: Exports by destination, around the 1880s, France and Belgium were, according to Argentinean records, the main destinations of exports but were overtaken by Britain and Germany around the turn of the century, and later by the US. A first view of the accuracy index by pairs of countries for Argentinean exports is offered in Figure 1. In the upper part of the figure we offer the accuracy indexes for the pairs of countries which represented the most common European destinations as transit ports, as is the case of British and Belgian destinations. As expected, both show a general overvaluation before the 1890s followed by a clear change to undervaluation positions during this decade and in the years around the turn of the century. In the lower part of Figure 1 we offer the accuracy indexes of the more distant countries such as France and Germany and, as expected, they offer a clearer undervaluation trend during the whole period. We analyse below which part of this cyclical bias is included in the total accuracy index and, in consequence, may also be partially explained by the general bias included in the total Argentinean official export records.

1720 per cent is the average c.i.f./f.o.b. estimated ratio for developing primary exports countries offered by Federico and Tena (1991, 266-7). 
Table 1: Argentine exports by destination: Shares on total exports (official data adjusted by "comercio a ordenes"). 5-year average

\begin{tabular}{|l|c|c|c|c|c|c|c|c|c|}
\hline & $\begin{array}{c}\text { United } \\
\text { Kingdom }\end{array}$ & $\begin{array}{c}\text { United } \\
\text { States }\end{array}$ & France & Germany & Belgium & Netherlands & Spain & Italy & Total \\
\hline $\begin{array}{l}1870- \\
1874\end{array}$ & $18 \%$ & $9 \%$ & $15 \%$ & $1 \%$ & $23 \%$ & & $3 \%$ & $3 \%$ & $72 \%$ \\
\hline $\begin{array}{l}1876- \\
1879\end{array}$ & $11 \%$ & $6 \%$ & $22 \%$ & $3 \%$ & $28 \%$ & & $2 \%$ & $3 \%$ & $74 \%$ \\
\hline $\begin{array}{l}1880- \\
1884\end{array}$ & $10 \%$ & $6 \%$ & $28 \%$ & $7 \%$ & $22 \%$ & & $2 \%$ & $3 \%$ & $78 \%$ \\
\hline $\begin{array}{l}1885- \\
1889\end{array}$ & $15 \%$ & $6 \%$ & $29 \%$ & $12 \%$ & $15 \%$ & & $2 \%$ & $3 \%$ & $83 \%$ \\
\hline $\begin{array}{l}1890- \\
1894\end{array}$ & $18 \%$ & $4 \%$ & $22 \%$ & $12 \%$ & $13 \%$ & & $2 \%$ & $3 \%$ & $74 \%$ \\
\hline $\begin{array}{l}1895- \\
1899\end{array}$ & $12 \%$ & $6 \%$ & $20 \%$ & $13 \%$ & $11 \%$ & & $1 \%$ & $3 \%$ & $66 \%$ \\
\hline $\begin{array}{l}1900- \\
1904\end{array}$ & $16 \%$ & $4 \%$ & $14 \%$ & $12 \%$ & $8 \%$ & & $1 \%$ & $2 \%$ & $56 \%$ \\
\hline $\begin{array}{l}1905- \\
1909\end{array}$ & $17 \%$ & $5 \%$ & $10 \%$ & $11 \%$ & $9 \%$ & $1 \%$ & $1 \%$ & $2 \%$ & $56 \%$ \\
\hline $\begin{array}{l}1910- \\
1913\end{array}$ & $25 \%$ & $6 \%$ & $9 \%$ & $12 \%$ & $8 \%$ & $3 \%$ & $1 \%$ & $4 \%$ & $69 \%$ \\
\hline
\end{tabular}

Source: Official national statistics. Adjustment "comercio a ordenes" see text.

Figure 2 shows the first exercise comparing the total sum of Argentina's export records and the corresponding import statistics of its partner countries (mirror statistics). We present the total sum of official Argentinean exports compared with their partners' import data records in US dollars. The countries included are those of Table 1 and the series are adjusted in two senses. First, we consider the "comercio a órdenes" as a proportion of the total sample of partner countries' records included and, second, we incorporate the freight factor and tariff export correction by product. So we compare import records to f.o.b. untaxed export records according to the weighted average for individual commodities' freight factor and export ad valorem product tax offered in Appendix 1. As mentioned above, "comercio a órdenes" problems are relevant from 1895 onwards. We assume that the improvement of the accuracy index from that year is driven by some improvements in the official values more than by the inclusion of "comercio a órdenes" as we will prove later offering the accuracy test by prices. The accuracy index of the adjusted series shows a moderate but persistent undervaluation in the official export series before 1889. The Baring crisis of 1889 offers an exceptional overvaluation probably produced by the fact that there was no revision of the official values of commodities such as wheat and 


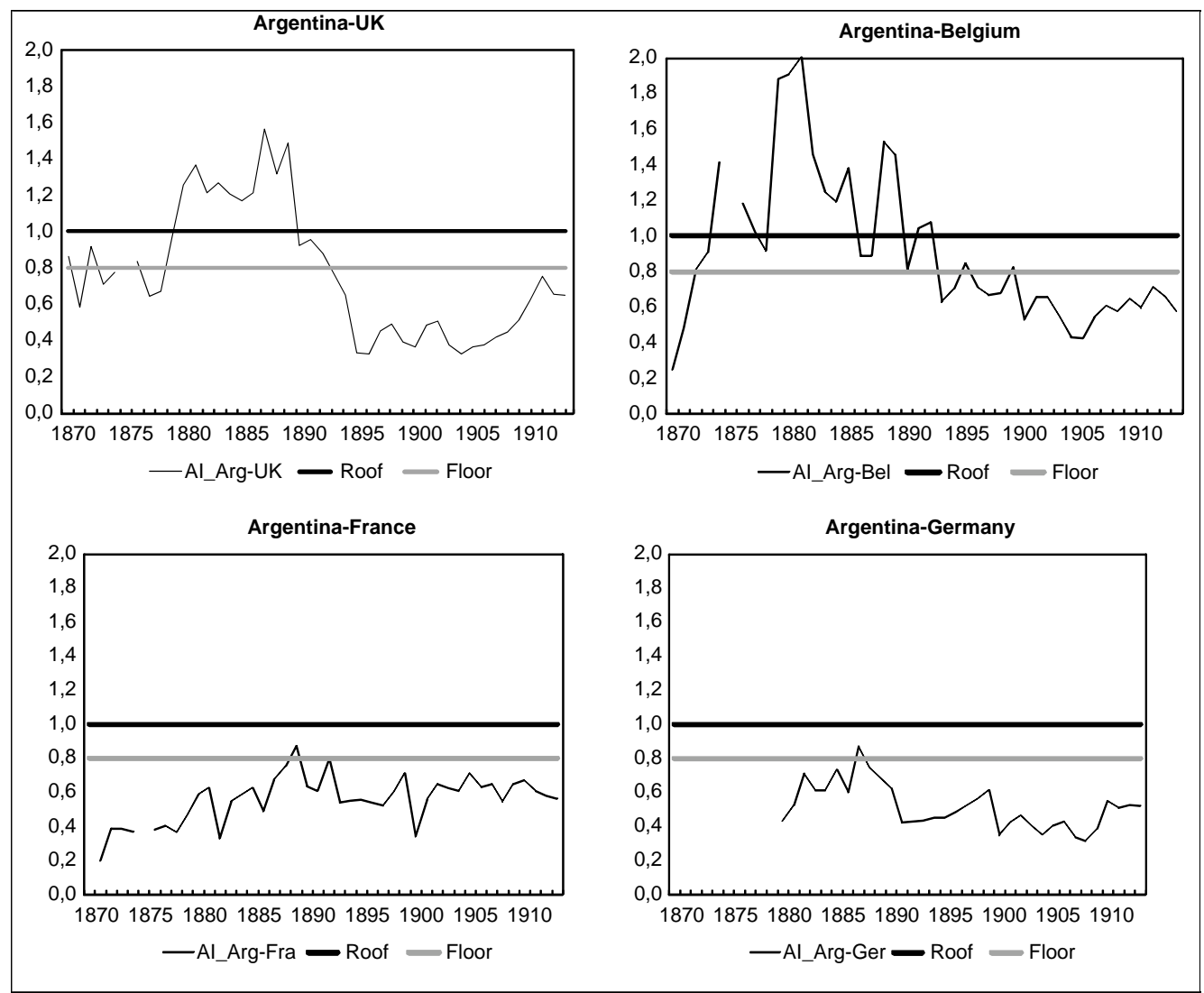

Figure 1: Accuracy index of Argentine exports by pairs of countries 1870-1913 (not c.i.f.-f.o.b. adjusted)

wool in a depression year. As previously mentioned, the literature suggests some interpretations of this persistent undervaluation before the First World War. The undervaluation hypothesis is based mainly on the incentives of exporters to undervalue official values to exaggerate tariff appearance. We also suggest that they were updated very infrequently for the same reason. ${ }^{18}$ Official export tariffs were specific, that is, they were paid based on the volume exported but were estimated and presented according to price. Export lobbies wanted official values as a reference of international transactions to be lower than market prices so that taxation appeared greater than it was in reality. This allowed exporters to claim tax reductions. The results in Figure 2 would confirm this interpretation in general terms but show a more moderate undervaluation than expected. The trend showed in Figure 2 is nevertheless cyclical, showing that when the international price trend

18 See the discussion in the previous section based on Dirección General de Estadística. Argentina (1913) and Cortes Conde, Halperin, and Gorostegui de Torres (1965). 


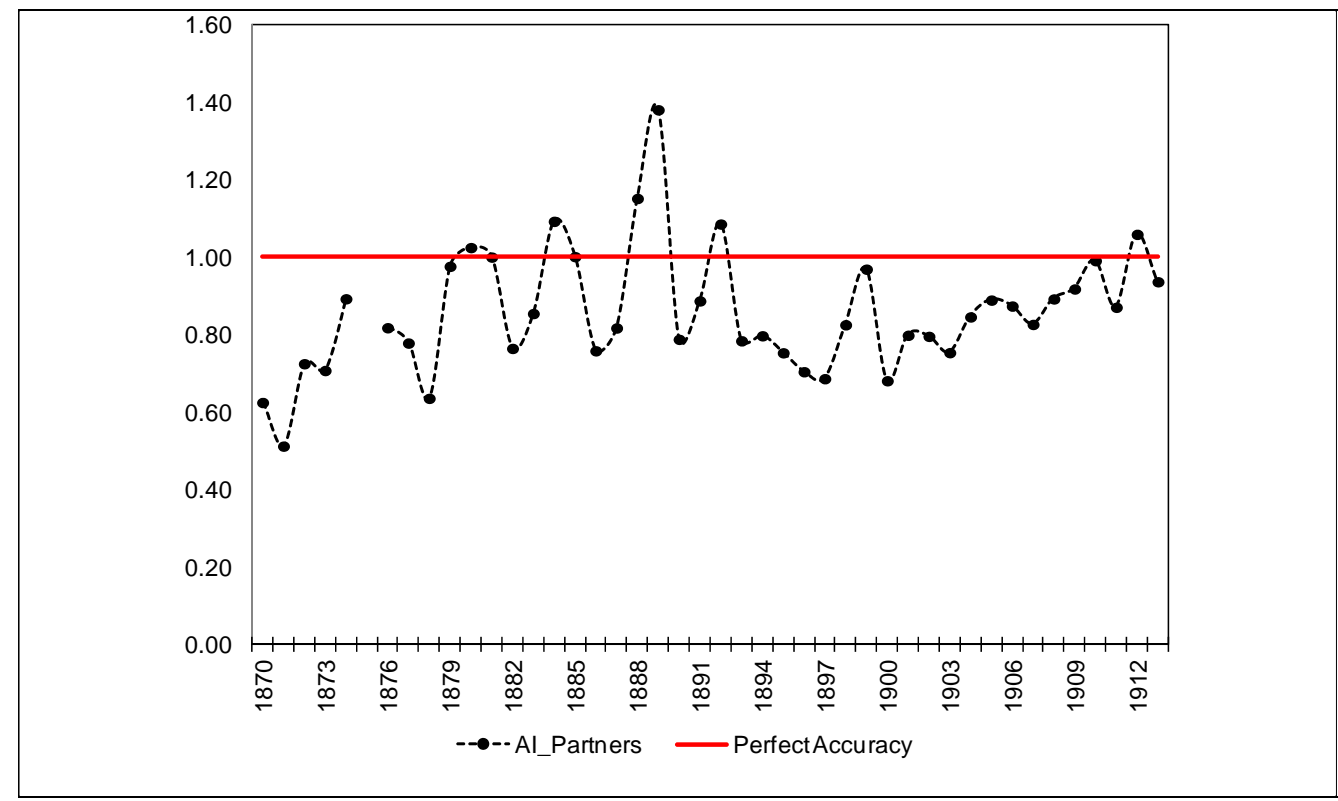

Figure 2: Argentine partner records adjusted accuracy index 1870-1913

Sources: Appendix 1 and Appendix 6.

went down, as happened between 1870 and the early 1890s, if official values were not updated, the undervaluation trend reduced. From early 1890 to the turn of the century undervaluation increased moderately but from those years to the First World War the literature considers that official values were better updated and this would explain the improvement in the accuracy index.

\subsection{The price accuracy index}

As suggested in the previous section, it is necessary to confirm whether the accuracy of Argentina's exports is mainly related with the reliability of official values. Consequently our second approach is to revaluate the official values of the main export products. Following the previous experience of Cortes Conde, Halperin, and Gorostegui de Torres (1965), we made a selection of the most important crop and cattle products exported (wheat, maize, linseed, wool, leather, beef meat, mutton meat) representing around 80 to 90 per cent of total exports. On the one hand, we estimate official values, summing values of different qualities of products divided by their respective quantities. Official sources were complemented with other secondary sources to avoid problems in the homogenization of the series because of changes in the quality of the products or typing errors. ${ }^{19} \mathrm{On}$ the other hand, we use two different independent sources for the estimations of international prices of the respective commodities: first, the official values (estimated by dividing the values and quantities) of the United Kingdom's records 
of imports from Argentina and, for comparison or as last resort, the well-known Sauerbeck series of international prices for primary commodities. ${ }^{20}$

In Appendix 2 we contrast Sauerbeck's commodity prices with UK-Argentina import prices. The former represent an average of international prices of primary products in London but we have some doubts about whether they represent Argentinean export commodity quality appropriately. We believe that the latter better reflect the average quality evolution of primary products exported by Argentina. From 1871, imports and re-exports in UK statistics were computed from declarations made by importers and re-exporters and not on the basis of prices supplied by dealers. Therefore Argentine imports in the UK have a different price to a similar product coming from another geographical origin with a different quality and freight cost. ${ }^{21}$

In the appendices we offer the annual freight rates (Appendix 3), the official values (Appendix 2), and the ad valorem export tax for each of the respective products. We include freight and tax adjustments used to translate the UKArgentina c.i.f. import prices to the corresponding f.o.b. export prices at the Argentine border before taxes and contrasted with the corresponding official Argentine official values. Figure 3 shows the accuracy index of the price sample (adjusted) for the years 1876-1913. Apparently the undervaluation average (around 14 per cent) and the cycles are quite similar to those in Figure 2. We can say, then, that both accuracy indexes constructed from different sources and procedures would confirm, on the one hand, and against what is assumed in the literature, that the Argentine export accuracy improvements did not arrive in 1892 but with the turn of the century. On the other hand, we see that undervaluation is cyclical but remains the main characteristic of the Argentine export series. However, it is necessary to delve deeper and contrast all the evidence.

Figure 4 presents the accuracy indexes shown in Figures 2 and 3 together with that derived from the data offered by Cortes Conde, Halperin, and Gorostegui de

19 We use official statistics from 1882 to 1892: Estadística del Comercio Exterior y de la Navegación de la República Argentina and from 1893 to 1915 Anuario del Departamento Nacional de Estadistica. The homogenization of the retrospective series is from Latzina (1905, 180-228), and Tornquist (1919, 167-72), and confirmed with Vazquez Presedo (1971a) and (1971b) for values and Ferreres (2005) for quantities.

20 The UK import quantities and values from Argentina are taken from several years of the Annual Statement of the Trade (1874, 1878, 1892, 1896, 1900, 1904, 1908, 1912 and 1915). The complete series of Sauerbeck's international commodity prices is from Sauerbeck $(1886,1893$, 1909 and 1917).

21 UK exports values were based on declarations made by exporters even before 1854. But import and re-export values were based on declaration for dealers until 1869. So for all practical purpose statistics of unitary values of UK exports and imports were from 1871 "declared values", following current international recommendations: "In 1871, then, the trade accounts reached essentially their present form ... They were based on importers and exporters declarations of values as well as quantities, collected by Customs Officers at the ports, and transmitted to the Custom Statistical Office for compilation." See Stafford, Matton, and Venning (1953), 291, and Imlah (1958), 44. 


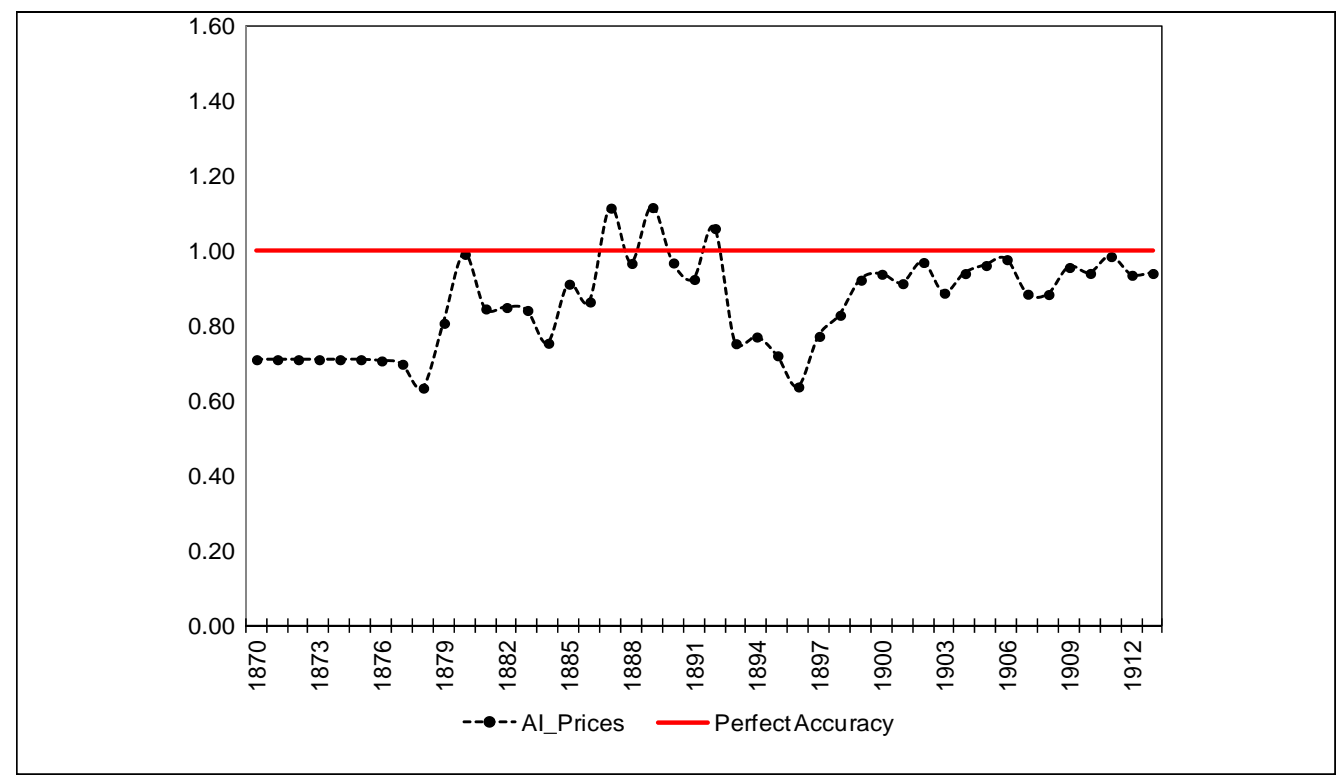

Figure 3: Argentine price sample adjusted accuracy index 1870-1913 Sources: see Appendix 2 and Appendix 6.

Torres (1965). The latter study uses a similar price sample but with domestic market prices instead of UK international prices. In general terms we get similar results in the undervaluation trend and cycles for the three series but these apparent similarities hide some relevant differences. First, our accuracy index based on Argentine-UK import price records compared with the accuracy index of the country partner records shows a higher undervaluation in the 1870s and 1880s, a similar undervaluation during the 1890s and a better accuracy index between the turn of the century and the First World War. Second, the Cortes Conde, Halperin, and Gorostegui de Torres (1965) accuracy index also shows a more moderate undervaluation for the 1870s and early 1880s but worse results for the second half of the 1880s including an unexpected and unexplained decreasing of more than 60 per cent in 1891. Third, the accuracy index of Cortes Conde, Halperin, and Gorostegui de Torres (1965) improves substantially from 1892 onwards because they assume that official prices of agrarian products (wheat, maize, linseed, and other corns and flour), which represent more than 40 per cent of total export value in those years, fit perfectly with domestic market prices. As mentioned in the previous section they only revaluate some cattle products from 1892 onwards. On the contrary, we revaluate every product including crop commodities throughout the whole period with international prices. This overcomes possible problems with exchange rate conversion in a period of strong depreciation of the peso and uncertainty about the monetary unit used by official statistics. Our results show a clearer export undervaluation during the Baring crisis years and its aftermath and from the turn of the century, a more consistent moderate but stable undervaluation which appears to reduce progressively from 1906 onwards. 


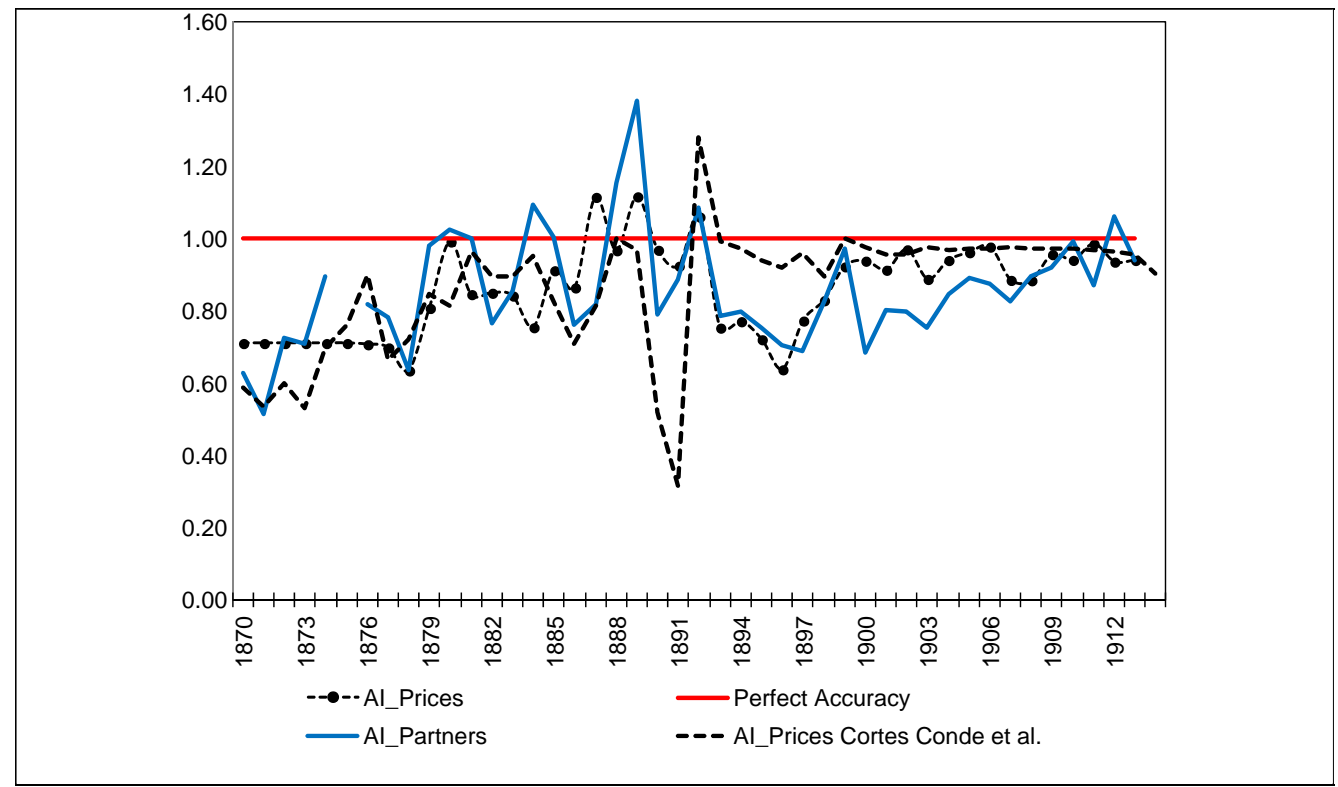

Figure 4: Argentine export accuracy index 1870-1913

Sources: see Appendix 1 and Appendix 2 and Cortes Conde et al. 1965, 42.

Figure 5 shows the contrast in our price accuracy index between the crop and cattle commodities partially confirming the literature's presumption that official values of cattle were mainly responsible for the general undervaluation of the Argentine export series. Before 1892, increasing international prices in cattle commodities (see cattle commodities prices in Appendix 2) would moderate the previous undervaluation of this group. On the contrary, for the same years, the official values of the crop commodities, with a share lower than 10 per cent of total exports, show a more erratic cyclical trend with extreme overvalued years. Contrary to the literature's presumptions from 1892, crops (whose share in total exports increased from a quarter in the 1890s to almost half at the turn of the century) present a stable undervaluation with a similar profile to cattle commodities. Different behaviour appears only from 1906 to 1913 when crop products improved their accuracy in contrast with a moderate increase in the undervaluation of cattle products.

As shown in Figure 6, during the 1870s and early 1880s the main cattle commodities (skins, wool, salted meat) were taxed at around 7 per cent, but from the second half of the 1880s tariffs were reduced to 2 to 3 per cent and increased again to 4 per cent in the 1890s, until they were abolished in 1906 (see Latzina 1905 and Cortes Conde, Halperin, and Gorostegui De Torres, 1965). The overall undervaluation trend was probably caused by tariffs but, in addition or because of that, general official values were not updated yearly. So the cyclical trend of international prices may help to understand the cyclical profile of the undervaluation. This would allow us to explain the fact that undervaluation persisted after tariffs were abolished in 1906 and that duty-free crop products were also undervalued showing a similar trend to cattle commodities at least from 1890s onwards. 


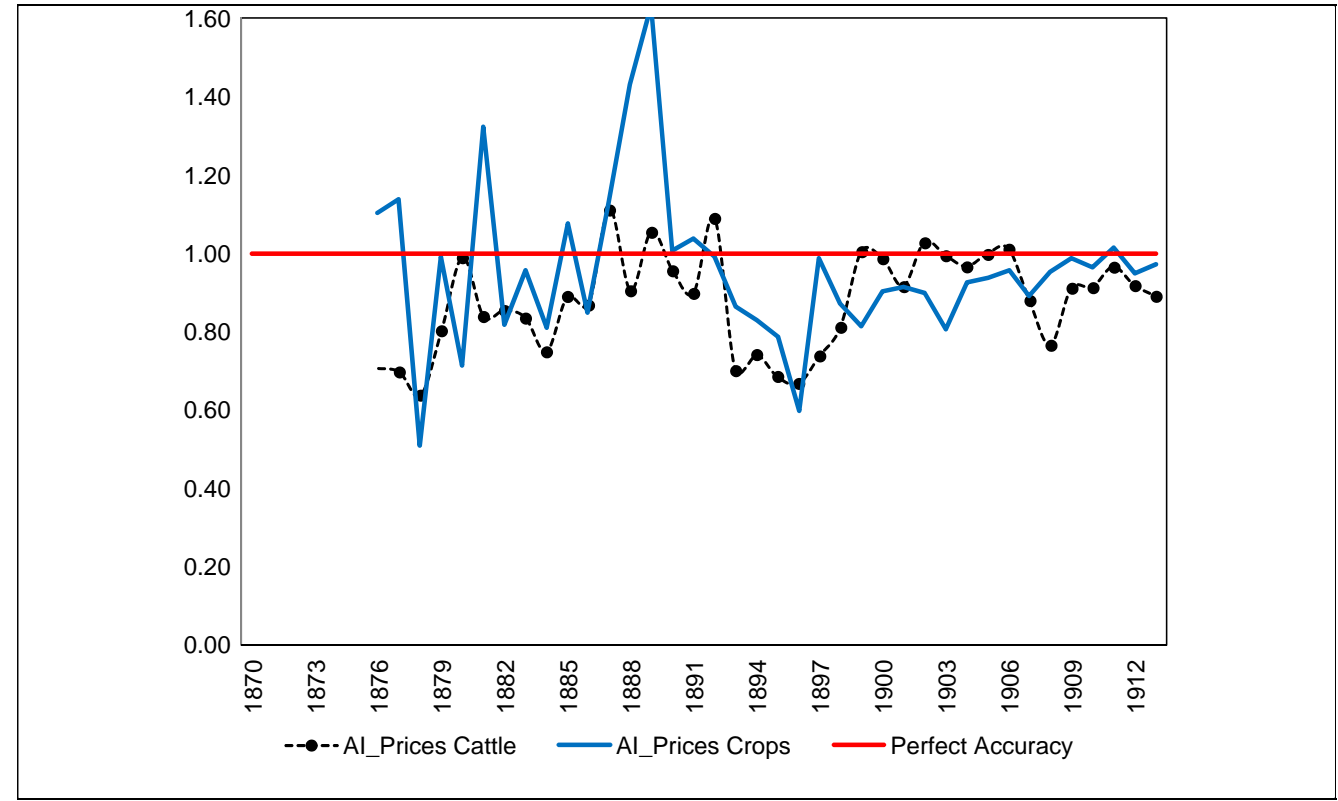

Figure 5: Price accuracy index (adjusted) of crop and cattle exports 1870-1913 Sources: see Appendix 2 and Appendix 5.

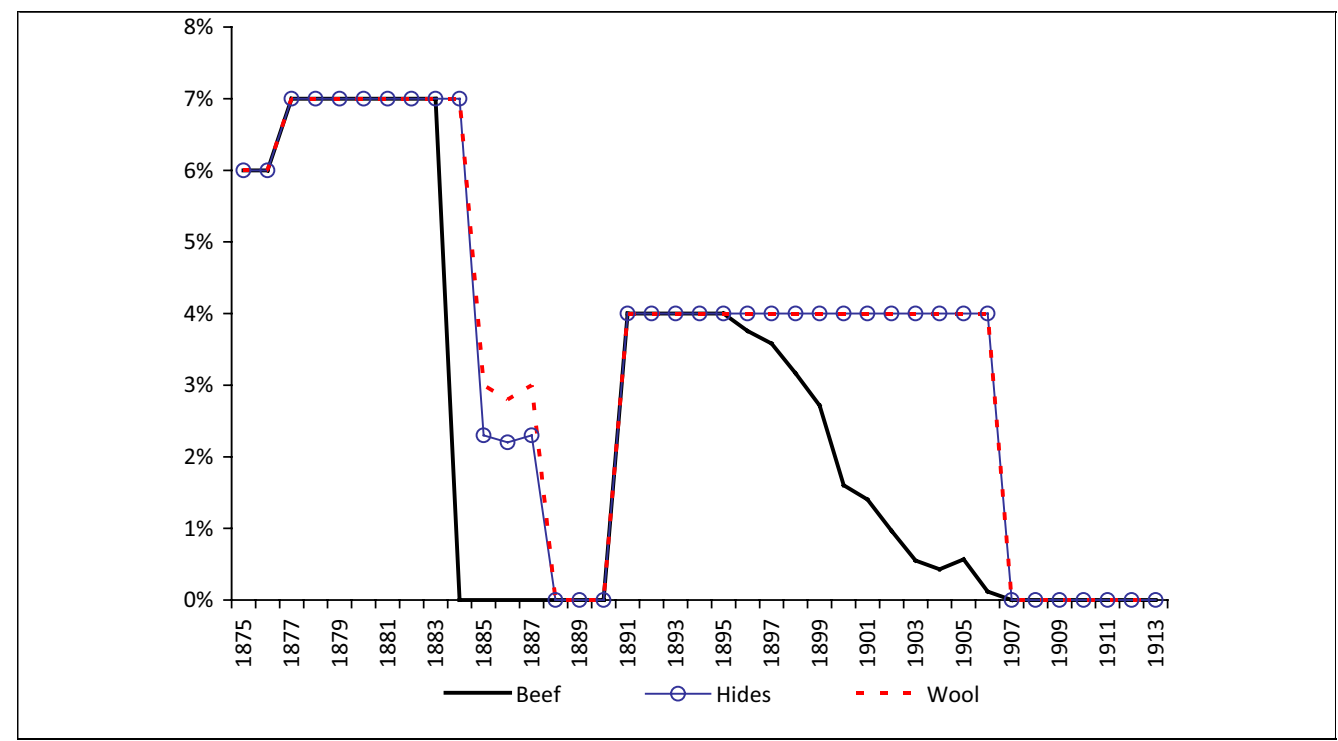

Figure 6: Argentine main tariff export rates

Note: The other products of our sample (mutton meat, linseed, maize and wheat) were free of tariffs throughout the whole period. Tariffs were specific but were usually presented in ad valorem terms over official values. For 1875-1904 see Latzina (1905, 181-219); for the rest of the years see Cortes Conde et al. (1965). 
The above would prove reasonably that Argentine export series are cyclical but significantly undervalued. Two independent tests contrasting the official series with the sum of partner import countries' records and with a sample of international prices of the commodities exported adjusted by tariff and freights would present a similar undervaluation profile providing reasonable proof that the origin of the bias is caused by the official price undervaluation of the main commodities exported.

\section{EXPORT PRICE INDEX AND THE ARGENTINE EXPORT GROWTH}

First, we present our new Argentine export f.o.b. price index. The trade structure of Argentina changed significantly during the period and we believe it is important to elaborate an index number capable of incorporating these changes in the calculations. Therefore we propose a Paasche index number and use exported quantities, year by year, to weight the respective prices corrected by our estimated freight-tariff annual factor. In Figure 7, we compare the total, crop and cattle new price indexes of Tena and Willebald (henceforth $\mathrm{T} \& \mathrm{~W}$ ).

Figure 7 shows how Argentina's export prices experienced a decreasing trajectory until the mid-1890s and, from then, prices recovered significantly until the First World War. Crop price reductions were more pronounced than cattle before 1895 but did not affect the total index because they represented a small share in total exports during that period (see Table 3 ). In the recent literature, the most extensively used export price index is that presented in Blatman, Hwang, and Williamson (2004) and Williamson (2000, 2002), based on Ford (1955) (henceforth BHW). Both indexes coincide in trends but the recovery of $\mathrm{T} \& \mathrm{~W}$ index from the $1890 \mathrm{~s}$ onwards meant bettering the levels achieved before the first globalization boom. In general,

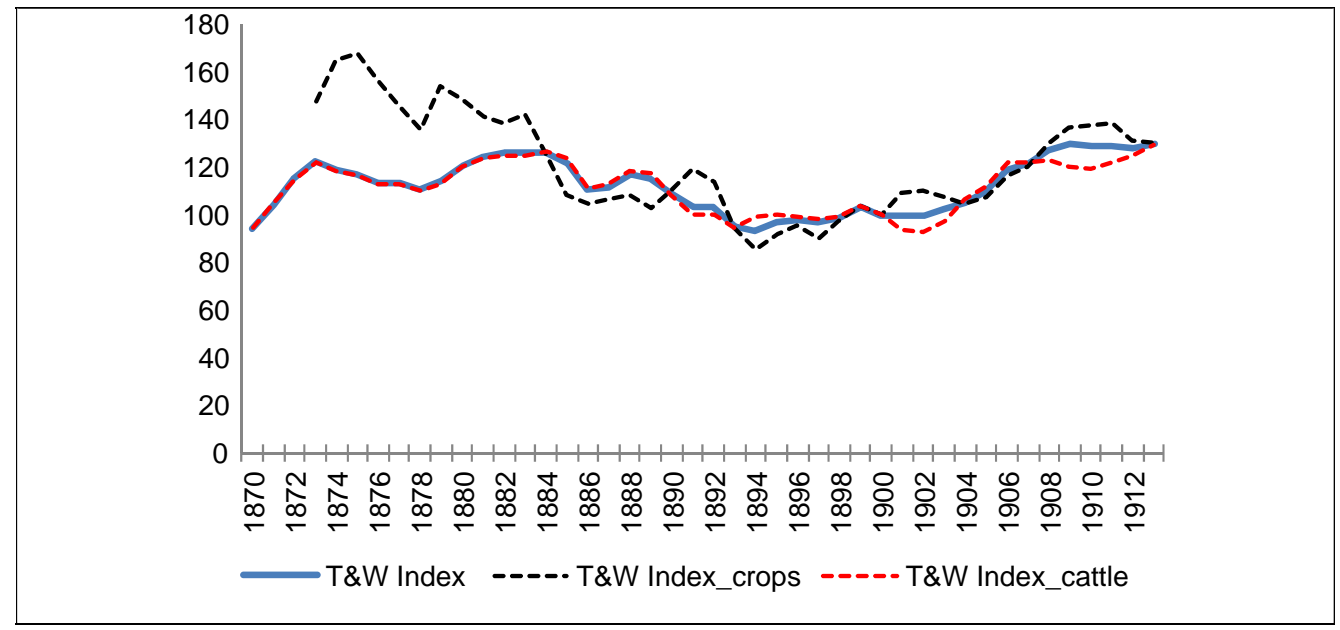

Figure 7: Argentine export price index 1870-1930 $(1899-1901=100)$

Sources: see Appendix 4 and Appendix 5. 
our Paasche price indicator offers a more stable evolution with a less pronounced decrease before 1895 and a slower subsequent increase than the previous index.

Comparative export growth offered by the new export volume series in Table 3: Argentine export growth rates 1870-1913 (constant prices) reveals a different growth trend in the respective series. Discrepancies are significant enough to distinguish different patterns during the period. The Tena and Willebald series shows, for $1870-1913$, a growth rate of 5.3 per cent that represents an intermediate record between the moderate 4.6 per cent of Cortes Conde, Halperin, and Gorostegui de Torres (1965) and the more dynamic 6.6 per cent that we would obtain applying the index price of Blatman, Hwang, and Williamson (2004). On the one hand, the export evolution of our series is very similar to that of Cortes Conde, Halperin, and Gorostegui De Torres (1965) during the first 20 years, but not in the next two decades, when the former indicates a better export performance than the latter. On the other hand, the Blatman, Hwang, and Williamson (2004) series shows more inconsistent growth during the period 1870-90 than in the years 1890-1913.

Table 3: Argentine export growth rates 1870-1913 (constant prices) and Figure 8 describe Argentine exports for the period 1870-1913 growing in two long waves separated by the "Baring crisis" at the end of the 1880s and a long readjustment in the 1890s. The first wave was led by traditional cattle products, which represented almost 90 per cent of total exports in the 1870s, while wool became the main protagonist in the $1880 \mathrm{~s}$, with a share of almost half of total exports. The second wave was led by maize and wheat which were already important and growing export commodities even before the Baring crisis, but expanded even faster following the international market dynamism of the first globalization period and their production cost reduction before the First World War. The data in Table 2 would show a more moderate expansion of exports before the Baring crisis. The growth of cattle exports was moderate in the 1870s but accelerated in the 1880s despite the cattle frontier movement initiated in the 1870 s and the military expedition in indigenous territory. The quantity of land used for crop increased by around 40 million hectares between 1867 and 1890 and this affected the most productive land in Argentina: la pampa húmeda (see Cortes Conde 1979, 55). ${ }^{22}$ Cattle frontier movement to less fertile territories partly explains the expansion of crop in more productive lands in the 1880s, as well as the disposal of more fertile land on which the export success of wheat between 1888 and 1894 was based. These trends were also temporally supported, during the international crisis years, by the fall in value of the domestic currency (see Cortes Conde 1979, 89-90). ${ }^{23}$ This land frontier movement was followed by market

22 The end of geographical expansion, according to Di Tella and Zymelman (1967), was also important to understand the different agrarian export growth in relation with other countries such as Canada and Australia.

23 See also the real exchange rate index in Figure 9. 
Table 2: Argentine main export commodities: Shares of total exports (corrected data). 5-year average

\begin{tabular}{|c|c|c|c|c|c|c|c|c|}
\hline & $1876-1879$ & $1880-1884$ & $1885-1889$ & $1890-1894$ & $1895-1899$ & $1900-1904$ & 1905-1909 & 1910-1913 \\
\hline Tallow & $8 \%$ & $6 \%$ & $5 \%$ & $4 \%$ & $4 \%$ & $4 \%$ & $4 \%$ & $4 \%$ \\
\hline Animals & $7 \%$ & $6 \%$ & $4 \%$ & $3 \%$ & $3 \%$ & $3 \%$ & $3 \%$ & $3 \%$ \\
\hline Beef & $8 \%$ & $7 \%$ & $6 \%$ & $8 \%$ & $5 \%$ & $5 \%$ & $7 \%$ & $10 \%$ \\
\hline Mutton & $0 \%$ & $0 \%$ & $2 \%$ & $3 \%$ & $4 \%$ & $5 \%$ & $3 \%$ & $3 \%$ \\
\hline Hides & $17 \%$ & $14 \%$ & $14 \%$ & $12 \%$ & $8 \%$ & $7 \%$ & $6 \%$ & $8 \%$ \\
\hline Wool & $49 \%$ & $58 \%$ & $51 \%$ & $35 \%$ & $37 \%$ & $23 \%$ & $19 \%$ & $12 \%$ \\
\hline Cattle & $90 \%$ & $90 \%$ & $83 \%$ & $65 \%$ & $60 \%$ & $47 \%$ & $42 \%$ & $40 \%$ \\
\hline Linseed & $0 \%$ & $1 \%$ & $2 \%$ & $2 \%$ & $4 \%$ & $9 \%$ & $9 \%$ & $9 \%$ \\
\hline Maize & $1 \%$ & $2 \%$ & $6 \%$ & $5 \%$ & $10 \%$ & $15 \%$ & $14 \%$ & $16 \%$ \\
\hline Wheat & $1 \%$ & $2 \%$ & $4 \%$ & $17 \%$ & $13 \%$ & $21 \%$ & $28 \%$ & $19 \%$ \\
\hline Crops & $1 \%$ & $5 \%$ & $13 \%$ & $24 \%$ & $27 \%$ & $44 \%$ & $52 \%$ & $44 \%$ \\
\hline Sample on total exports & $91 \%$ & $95 \%$ & $95 \%$ & $89 \%$ & $87 \%$ & $92 \%$ & $93 \%$ & $84 \%$ \\
\hline
\end{tabular}

Sources: new series of products corrected by f.o.b. adjusted prices from Appendix 2 Table A.2.1. Tallow and animals corrected with total cattle prices adjusted. 
Table 3: Argentine export growth rates 1870-1913 (constant prices)

\begin{tabular}{|l|c|c|c|c|}
\hline & $\begin{array}{c}\text { Total exports } \\
\text { c.i.f. }\end{array}$ & $\begin{array}{c}\text { Total exports } \\
\text { f.o.b. }\end{array}$ & $\begin{array}{c}\text { Total exports } \\
\text { f.o.b. }\end{array}$ & $\begin{array}{c}\text { Cattle exports } \\
\text { f.o.b. }\end{array}$ \\
\hline $\begin{array}{l}\text { Blatman et al. } \\
1870- \\
1880\end{array}$ & 4.7 & $\begin{array}{c}\text { Cortes Conde } \\
\text { et al. }\end{array}$ & $\begin{array}{c}\text { Tena-Willebald } \\
\text { Total }\end{array}$ & $\begin{array}{c}\text { Tena-Willebald } \\
\text { Cattle }\end{array}$ \\
\hline $\begin{array}{l}1880- \\
1890\end{array}$ & 8.9 & 4.9 & 0.8 & 2.6 \\
\hline $\begin{array}{l}1890- \\
1900\end{array}$ & 3.8 & 4.1 & 7.0 & 6.3 \\
\hline $\begin{array}{l}1900- \\
1913\end{array}$ & 8.5 & 6.4 & 5.6 & 0.7 \\
\hline $\begin{array}{l}1870- \\
1890\end{array}$ & 6.8 & 3.7 & 7.5 & 6.5 \\
\hline $1890-$ & 6.4 & 5.4 & 3.8 & 4.4 \\
1913 & 6.6 & 4.6 & 6.7 & 3.9 \\
\hline $1870-$ & & & 5.3 & 4.2 \\
\hline 1913
\end{tabular}

expansion accompanied by the railway development and the reduction of Atlantic freight rates. Our data show that after the Baring crisis in the early 1890s, finance problems apparently affected cereal exports as much as those of wool in the short run. However, through the decade of the 1890s these problems acted negatively mainly on cattle but not on wheat as shown by the dynamism of crop exports. The

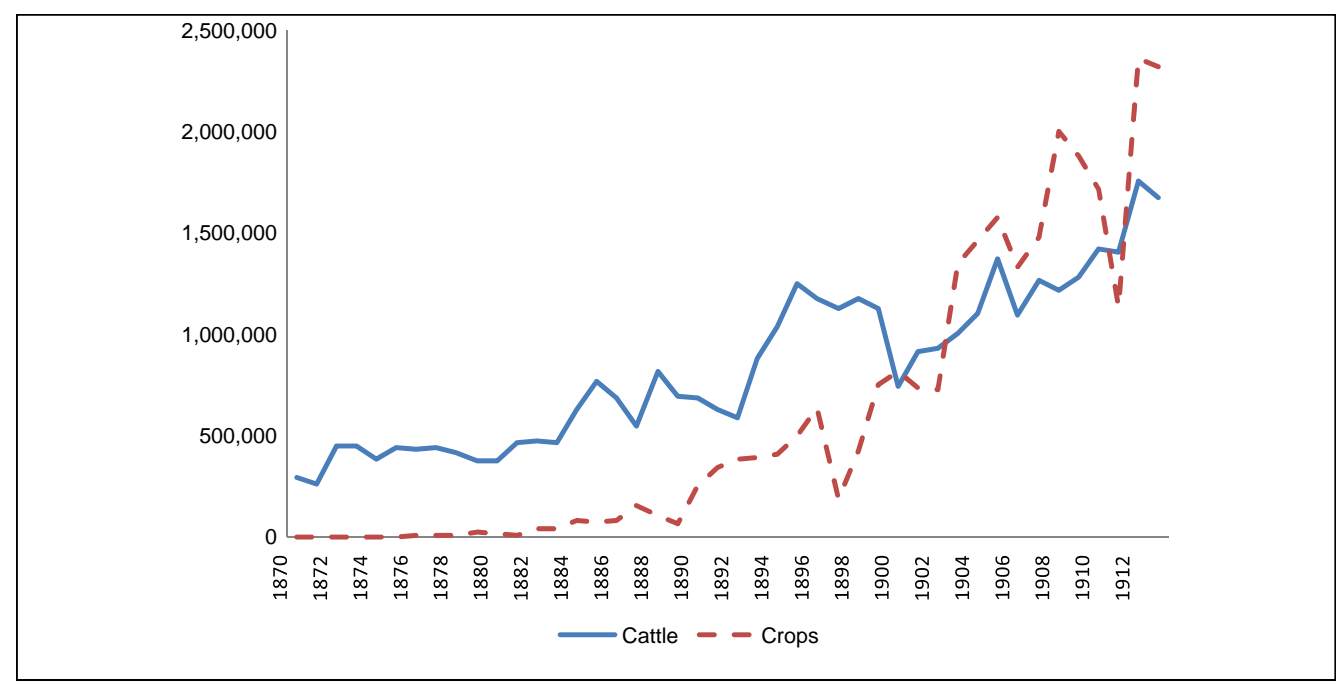

Figure 8: Argentine cattle and crop exports constant prices (pesos oro) 1870-1913 Sources: see Appendix 5. 
strong monetary depreciation of the Baring crisis slowed down the entrance of new capital but this, in fact, had a less dramatic effect on export performance than the literature has assumed.

At the end of the 19th century the rapid development of cereal production took place alongside demographic changes, immigration growth and capital flows that supported the extension of the railway network. Argentina's export commodity structure (see Table 2) shows this important transformation of the agrarian development clearly. In the 1870 s and 1880s the traditional cattle products - wool, tallow, hides, live animals, and beef meat - account for more than 80 per cent of total exports and it was only in the early 1890s when crop commodities, especially wheat, expanded for the first time, pushed by currency depreciation and the previous land expansion in the "Pampa húmeda". The extraordinary expansion of the export share of wheat from 4 per cent in 1885-9 to 17 per cent in the period 1890-94 is striking in the context of the years immediately following the Baring crisis. In parallel we can observe a significant fall in the share of the most representative export cattle commodities such as wool and hides. Despite this remarkable first expansion of crop exports, it was not until after the turn of the century, in the period previous to the First World War, that crops would lead Argentine export growth. The export shares of wheat, maize and linseed increased rapidly during the first years of the new century, and beef, pushed by the consolidation of transatlantic shipping's refrigeration technology, was mainly responsible for the last years of Argentina's export expansion.

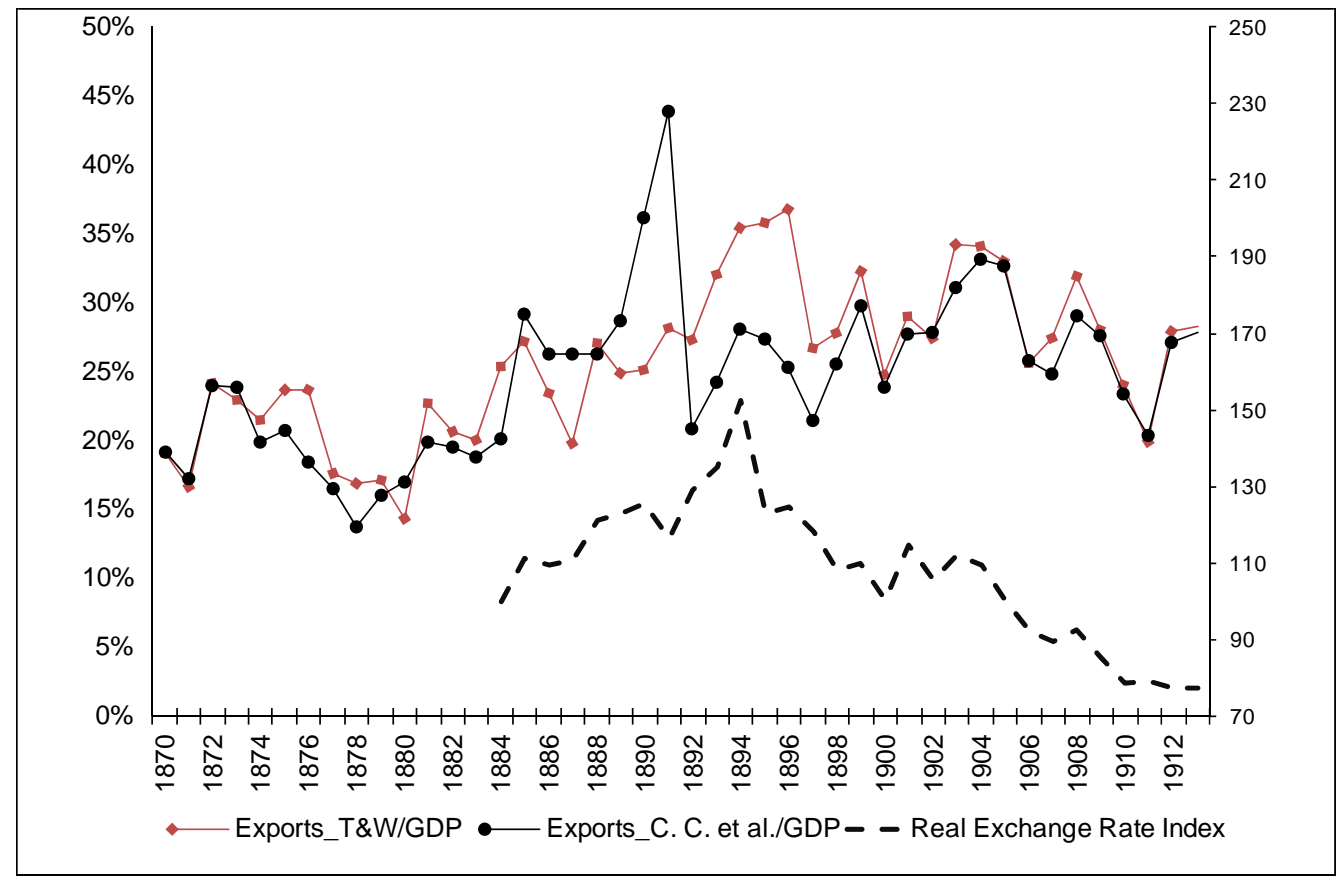

Figure 9: Argentine Export/GDP ratio, 1870-1913, current prices (pesos oro)

Sources: Appendix 5, Della Paolera and Taylor 2003, Maddison 2001, and Williamson 1999. 
Our new estimation fits this historical context consistently, showing a better export performance during the Belle Époque years than the figures offered by Cortes Conde, Halperin, and Gorostegui de Torres (1965). It also indicates improved cattle, and especially meat-related, export performance before the First World War. Finally, it shows a more dynamic long-run export performance than the literature and alternative series have showed.

To conclude, we test our results estimating the Exports/GDP ratio to underline the relevance of external transactions in the domestic economy and to evaluate the dynamics of Argentina's export-led growth strategy in the last third of the 19 th century. ${ }^{24}$

In Figure 9 we present our series (Exports_T\&W/GDP) together with the "corrected" series derived from Cortes Conde, Halperin, and Gorostegui de Torres (1965). The main differences between the ratios emerge when we try to explain the first wave of openness expansion. On the one hand, Cortes Conde, Halperin, and Gorostegui de Torres (1965) show that the wave in the openness growth in Argentina would finish at the end of the 1880s, at the same time as the credit crunch associated with the Baring crisis. On the other hand, Tena-Willebald ratio growth is extended to the second half of the 1890s, which fits better with the depreciation of the real exchange rate during the first half of the 1890s. The real appreciation of the exchange rate ${ }^{25}$ during the second half of the 1890 s seems to stop the export expansion in relation with the GDP. During the Belle Epoque years, Tena-Willebald export growth offers a more dynamic performance than both the official and the "corrected" series, but this is not the case for the export ratio that shows a contracted trend during these years. Argentine openness ratio is twice the initial levels, but the expansion finished at the turn of the century with a fluctuation ratio around 30 per cent. This may be explained in a context of exchange rate appreciation and, additionally, because GDP expansion was based on a more diversified economy with larger internal markets and a relatively higher participation of non-tradable goods in the economy. By and large, our correction means accepting higher export levels and a better performance than the "standard" series and, at least partially, they show a more sensitive reaction to international conditions.

24 GDP in current prices is available from 1884 onwards (Della Paolera and Taylor, 2003) and converted to pesos oro in line with Alvarez (1929), pp. 115-120. For the previous period we discounted the movement in volume (Cortes Conde, 1994, for 1875-83; Maddison, 2001, for 1870-74) and prices (Williamson 1999), assuming the CPI as a good proxy for the GDP deflator.

25 We use a simple indicator of the evolution of the real exchange rate (RER) as the ratio between the wholesale prices (Della Paollera and Taylor, 2003) and the nominal exchange rate. 


\section{CONCLUSIONS}

The present study has discussed the accuracy of official Argentine exports in order to reconstruct a new current and constant value series for the period 1870-1913. Based on the literature we have discussed the accuracy problems of the monetary units, geographical distribution and, especially, official export unit values. We have used empirical evidence to test the accuracy of quantities and value records, first, according to import partners' records and, second, according to international market prices. We subsequently reconstructed a new Argentine export f.o.b. values and price index using international prices valued in sterling pounds, which allows us to present a new proposal concerning Argentine export growth.

Our results are, in general, similar to the Cortes Conde, Halperin, and Gorostegui de Torres (1965) estimation, confirming the undervaluation hypothesis. The main differences are to be found in the early 1890s, mainly because, unlike Cortes Conde, Halperin, and Gorostegui de Torres, we revaluate official values of crop commodities. In terms of the political economy reasons for the undervaluation hypothesis, we confirm that statistical records of official values were lower than market prices probably because exporters were interested in showing apparently higher ad valorem tariffs to support political claims in favour of tax reduction. Cattle commodities were tariff-taxed, unlike crop commodities which were freeexported. Our results show that official values of both commodities were undervalued but the former appear more consistently undervalued than the latter. It should be pointed out, however, that both trends are cyclical. Our hypothesis is that undervaluation was cyclical because when the international price trend fell, as happened between 1870 and the early 1890s, official values were not updated and the undervaluation was reduced. From the early 1890s to the turn of the century, undervaluation increased moderately but from that period to the First World War the literature considers that official values were better updated, and this would explain the improvement in the accuracy index.

The new series would offer a more dynamic export performance for most of the period than the literature and previous series have showed. We confirm that Argentine exports through the period 1870 to 1913 grew in two long waves separated by the Baring crisis at the end of the 1880s and a long readjustment in the 1890s. The first wave was led by traditional cattle products such as wool and the second wave by maize and wheat. Both commodities were already important, increasing export commodities even before the Baring crisis but grew faster following the international market expansion and the increase in productivity before the First World War. On one hand, the Baring crisis produced a strong monetary depreciation and slowed down the entrance of new capital. This affected investment and domestic production more than export performance as shown by their respective GDP ratios until the end of the 1890s. On the other hand, our figures show a more rapid export growth during the Belle Époque years than the figures offered by Cortes Conde, Halperin, and Gorostegui de Torres (1965). This situation was mainly caused by crop exports and improved cattle exports. But 
despite this improved export performance, our figures would confirm that, contrary to what happened during the $1880 \mathrm{~s}$, domestic growth accompanied export growth during the Belle Époque years.

\section{ACKNOWLEDGEMENTS}

Previous versions of this article were presented in the seminar Trade and Poverty in Madrid 2012, CLADHE III (Bariloche, 2012), XVIth WEHC (Stellenbosch, 2012). In this version we hope to answer most of the comments received from Roberto Cortes Conde and we would also like to thank Gerardo della Paolera, Luis Bértola, Agustina Rayes, and Jeffrey Williamson, for their comments. Valuable advice from the editor of this journal and especially from one of the referees also helped to improve this version considerably. The authors acknowledge financial support from the Spanish project MCI ECO2001-25713.

\section{REFERENCES}

Alvarez, J. 1929. Temas de historia económica argentina. Buenos Aires, El Ateneo.

Blatman, J., J. Hwang, and J. Williamson. 2004. The impact of the terms of trade on economic development in the periphery, 1870-1939: Volatility and secular change. NBER WP 10600, National Bureau of Economic Research, June.

Borcherding, T., and E. Silberberg. 1978. Shipping the good apples out: The Alchian and Allen Theorem reconsidered. Journal of Political Economy 86, no. 1: 131-8.

Bunge, Alejandro, E. 1918. Intercambio económico de la República, 1910-1917. Buenos Aires: Talleres Gráficos Argentinos.

Carreras-Martin A.Y., and M. Badia-Miro. 2008. La fiabilidad de la asignación geográfica en las estadísticas de comercio exterior: América Latina y el Caribe (1908-1930). Revista de Historia Económica /Journal of Iberian and Latin American Economic History 3, no. 26: $323-54$.

Cortes Conde, R. 1979. El progreso argentino 1880-1914. Buenos Aires: Editorial Sud Americana.

Cortes Conde, R. 1994. Estimaciones del producto bruto interno de Argentina 1875-1935. Departamento de Economía, Universidad de San Andrés, Agosto.

Cortes Conde, R., D. Halperin, and H. Gorostegui De Torres. 1965. Evolución del comercio exterior argentino: exportaciones 1864-1963. Parte Primera 1864-1930. Departamento de Bibliotecas. Secretaria de Estado de Programación y Coordinación Económica. Ministerio de Economía de la República Argentina: pp. 1-148. Working Paper Restricted.

Della Paolera, G., and A. Taylor. 2001. Straining at the anchor: The Argentine Currency Board and the search for macroeconomic stability, 1880-1935. National Bureau of Economic Research, Chicago: University of Chicago Press.

Della Paolera, G., and A. Taylor, eds. 2003. A new economic history of Argentina. Cambridge: Cambridge University Press.

Diaz Alejandro, C.F. 1970. Essays on the economic history of the Argentine Republic. New Haven: Yale University Press. 
Dieguez, H. 1972. Crecimiento e inestabilidad del valor y el volumen físico de las exportaciones argentinas en el periodo 1864-1963. Desarrollo Económico 12, no. 46: 333-49.

Dirección General de Estadística. Argentina. 1913. Anuario de la Dirección General de Estadística. Buenos Aires: Compañía Sud-Americana de Billetes de Banco.

Di Tella, G., and M. Zymelman. 1967. Las etapas del desarrollo económico argentino, Buenos Aires: Editorial Universitaria de Buenos Aires.

Federico, G., and Tena, A. 1991. On the accuracy of international foreign trade statistics (1909-1935). Morgenstern revisited. Explorations in Economic History 28, no. 3.

Ferreres, O. (dir.) 2005. Dos Siglos de Economía Argentina (1810-2004). Buenos Aires: El Ateneo.

Ford, A.G. 1955. Export price indices for the Argentine Republic, 1881-1914. Inter-American economic affairs, Autumn.

Imlah, A.H. 1958. Economic elements in the Pax Británica. Studies in British foreign trade in the nineteenth century. Cambridge, MA: Harvard University Press.

Hummels, D., and A. Skiba. 2004. Shipping the good apples out? An empirical confirmation of the Alchian-Allen Conjecture. Journal of Political Economy 112, no. 6: 1384-1402.

Latzina, F. 1905. Estadística retrospectiva del comercio exterior Argentino 1875-1904. Buenos Aires Compañía Sud Americana de Billetes de banco.

Llorca-Jaña, M. 2011. To be waterproof or to be soaked: Importance of packing in British textile exports to distant markets. The cases of Chile and the River Plate, c.1810-1859. Revista de Historia Económica. Journal of Iberian and Latin American Economic History 29, no. 1: 11-37.

Maddison, A. 2001. A millennial perspective. Development Centre Studies, Organization for Economic Cooperation and Development (OECD), Paris.

Mitchell, B.R. 2007. International historical statistics: the Americas, 1750-2005. Basingstoke: Palgrave Macmillan.

Rayes, A. 2010. "Las exportaciones argentinas durante la Gran Expansión. Productos y destinos 1890-1913". Paper presented in the II Congreso Latinoamericano de Historia Económica, Mexico.

Rappoport, M. 1990. Economía e historia: Contribución a la historia económica Argentina. Buenos Aires: Editorial Tesis.

Regalsky, A. 1986. Las inversiones extranjeras en la Argentina (1860-1914). Buenos Aires: Centro Editor de América Latina.

Regalsky, A. 2002. Mercados, inversores y elites. Buenos Aires: Editorial Nueva Sociedad.

Sanz-Villarroya, I. 2004. Las tendencias a largo plazo de la economía Argentina: 1875-1990. Revista de Historia Económica 22, no. 1: 177-205.

Sauerbeck, A. 1886. Prices of commodities and the precious metals. Journal of the Statistical Society of London 49, no. 3 (September 1886): 581-648.

Sauerbeck, A. 1893. Prices of commodities during the last seven years. Journal of the Royal Statistical Society 56, no. 2 (June 1893): 215-54.

Sauerbeck, A. 1909. Prices of commodities in 1908. Journal of the Royal Statistical Society 72 , no. 1: $68-80$.

Sauerbeck, A. 1917. The "STATIST'S” Index Numbers, in continuation of Mr. A. Sauerbeck's figures. Journal of the Royal Statistical Society 81, no. 2 (March 1918): 334-49. 
Stafford, J., J.M. Matton, and M. Venning. 1953. United Kingdom. In International Trade Statistics, ed. R.G.D. Allen and J.E. Elly, Ch. 14. New York: Chapman and Hall.

Taylor, A.M. 1992. External dependence, demographic burdens and argentine economic decline after the Belle Époque. Journal of Economic History 52: 907-36.

Tena-Junguito, A. 1992. Las estadísticas históricas del comercio internacional (1890-1960): fiabilidad y comparabilidad. Madrid: Banco de España, Estudios de Historia Económica, no. 24.

Tornquist, E. 1919. The economic development of the Argentine Republic in the last fifty years. Buenos Aires: Ernesto Tornquist \& Co.

Vazquez-Presedo, V. 1971a. El caso argentino: migración de factores comercio exterior y desarrollo, 1875-1914. Buenos Aires: Editorial Universitaria de Buenos Aires.

Vázquez-Presedo, V. 1971b. Estadísticas históricas Argentinas. Buenos Aires: (Comparadas). Primera Parte 1875-1914. Buenos Aires: Ediciones Macchi.

Williamson, Jeffrey. 1999. Real wages, inequality, and globalization in Latin America before 1940. Revista de Historia Económica 17, special issue: 101-42.

Williamson, J. 2000. Land, labour and globalization in the pre-industrial third world. NBER Working Paper Series 7784. National Bureau of Economic Research, Cambridge, MA, July.

Williamson, J. 2002. Land, labour and globalization in the third world, 1870-1940. Journal of Economic History 62, no. 1: 55-85. 


\section{APPENDIX 1: EXPORT PARTNER RECORDS ACCURACY INDEX}

We used import records of the main export trade partners of Argentina before the First World War to compare the total value of Argentina's official exports (according to official or local statistics) with the sum of these flows as registered by its partner countries' records (United Kingdom, the United States, France, Germany, Belgium, the Netherlands, Italy and Spain) as imports (1870-1913). We also include the series "comercio a órdenes" from 1895 to 1913 assuming that it reproduces the geographic distribution of the rest of the exports. Consequently, the data for comercio a órdenes are included taking into consideration only the annual per centage for the group of our eight main trade partners. Our formula is the following:

$$
X A I_{i}=\frac{\sum_{j=1}^{N} X_{i j}}{\sum_{j=1}^{N} M_{i j}}
$$

Where,

$X A I_{i}$ is the export partner records Accuracy Index of country $i$ (Argentina in our case).

$X_{i j}$ : is the value exported from country $i$ to country $j$, with $j=$ each one of the main geographical destination of exports of country $i$ (United Kingdom, the United States, France, Germany, Belgium, the Netherlands, Italy and Spain).

$M_{i j}$ is the value imports records by country $j$ from country $i$, according to official local records.

$M$ is valued at international c.i.f. prices. We get f.o.b. prices free of tax in Argentine border according to export tax and freight factor data offered in Figure 6 and Table A.3.1, respectively.

All data are expressed in US dollars. Sources and references are detailed in Appendix 6. For Argentine exchange rates we use different sources in accordance with the currency of export original data.

1870-1881: original pesos fuertes (implicit exchange rate in Board of Trade Foreign Countries, several years) and Officer (2001).

1881-1909: original data in pounds (Vazquez Presedo 1971) and exchange rate from Officer (2001).

1910-1913: original data in pesos argentinos (DGEN 1958) and exchange rate from Dieguez (1972), 346.

\section{APPENDIX 2: PRICE ACCURACY INDEX}

We re-evaluate the export records of Argentina's main commodities before the First World War to compare (the total value) of Argentina's official exports 
(according to official or local statistics) with the sum of the flows derived from the valuation of the official volume (quantities) export records at international prices (expressed in pounds). The previous literature used either domestic market prices "valores de plaza" (see Cortes Conde, Halperín, and Gorostegui de Torres 1965) or the well-known Sauerbeck commodity price series (see Blatman et al. 2004). Following price demand theory we believe that the quality of Argentine commodities exported to high-income markets tended to be superior to that corresponding to local market goods and, in consequence, we assume that Argentine export prices were more related with international prices than with domestic ones. ${ }^{1}$ For this reason, we work with two different series of international prices. On the one hand, we use prices derived from the extensive work of Augustus Sauerbeck on average commodity prices quoted on the London market. On the other hand, we use the declared import unit values from Argentina recorded by the Annual Statement of United Kingdom. We compare the evolution and consistency of both in Figures A2.1 to A2.7 below. The former, as mentioned above, was previously used for the estimation of Argentina's export price index in Blatman et al. (2004) (in c.i.f. values). The latter, as far as we know, has not been used previously either in the estimation of the price accuracy index or in the estimation of Argentina's export price index. We consider the latter series as the best proxy to the international prices that were in fact obtained by Argentine exporters. We base our choice on the following arguments.

Sauerbeck's prices constitute an average of commodities of different quality coming to the London market from different origins. From the supply side, the first globalization was a period with major changes in transport technology (refrigeration, as mentioned in the text, was incorporated in different countries at different stages) and in the agrarian production (fencing, cattle cross breeding). From the demand side, the geographical origin and the quality of commodities demanded by Britain changed significantly during this period with the rapid emergence of new suppliers and movements in local preferences (associated with increasing incomes). UK import declared values capture quality changes by geographical origin better than other official unitary values from other reputed continental trade records. Despite the fact that the UK was not permanently the main destination of Argentine exports, in the long run, it was the main market for most Argentine commodities. In consequence we assume that the UK's records of declared import unitary values capture differences in the quality composition of Argentine commodity exports better than the average proposed in Sauerbeck's series. Therefore, our general proposal is to use the unit values of the commodities imported by the UK from Argentina according to British records as a reference

1 The model that predicts that products of better quality will be exported is presented in "Shipping the good apples out" (Borcherding and Silberberg 1978). It has been discussed for a long time as part of price demand theory. Assuming shipping cost is equal in good and bad quality products, high quality products will become relatively cheaper in foreign markets. For a recent discussion, see Hummels and Skiba (2004). 
Table A2.1: Commodity export f.o.b. prices (tax and freight adjusted) converted to pesos oro per ton at fixed exchange rate)

\begin{tabular}{|c|c|c|c|c|c|c|c|}
\hline & Beef & Mutton & Hides & Wool & Linseed & Maize & Wheat \\
\hline 1870 & 156.64 & 128.65 & 269.05 & 223.10 & 66.12 & 27.25 & 50.53 \\
\hline 1871 & 163.48 & 136.48 & 277.72 & 286.90 & 66.03 & 29.66 & 62.01 \\
\hline 1872 & 168.53 & 142.32 & 298.63 & 407.94 & 66.80 & 25.48 & 65.22 \\
\hline 1873 & 72.43 & 146.98 & 334.02 & 382.91 & 65.16 & 26.24 & 69.48 \\
\hline 1874 & 74.43 & 124.20 & 363.46 & 374.01 & 62.47 & 34.62 & 63.08 \\
\hline 1875 & 117.11 & 158.74 & 330.62 & 343.30 & 57.84 & 31.17 & 53.39 \\
\hline 1876 & 149.50 & 158.60 & 311.83 & 363.79 & 54.39 & 32.51 & 41.22 \\
\hline 1877 & 129.04 & 138.41 & 292.52 & 329.03 & 56.99 & 28.19 & 53.26 \\
\hline 1878 & 192.93 & 147.16 & 281.76 & 335.64 & 52.09 & 24.13 & 55.26 \\
\hline 1879 & 149.47 & 135.84 & 242.36 & 352.85 & 55.54 & 21.81 & 42.81 \\
\hline 1880 & 130.33 & 138.60 & 279.41 & 369.03 & 57.47 & 30.15 & 48.28 \\
\hline 1881 & 186.19 & 147.00 & 245.40 & 436.76 & 52.77 & 26.14 & 45.82 \\
\hline 1882 & 264.78 & 161.23 & 260.54 & 355.03 & 46.28 & 33.06 & 59.30 \\
\hline 1883 & 197.29 & 169.70 & 271.93 & 362.72 & 42.63 & 30.23 & 42.72 \\
\hline 1884 & 310.99 & 188.41 & 370.95 & 394.95 & 39.39 & 24.66 & 37.16 \\
\hline 1885 & 252.08 & 206.20 & 333.99 & 362.81 & 44.46 & 21.31 & 32.25 \\
\hline 1886 & 165.31 & 151.60 & 250.88 & 315.82 & 43.24 & 19.64 & 29.37 \\
\hline 1887 & 110.30 & 132.56 & 253.84 & 316.68 & 38.36 & 20.98 & 32.34 \\
\hline 1888 & 160.39 & 157.53 & 231.85 & 459.85 & 38.27 & 23.51 & 31.87 \\
\hline 1889 & 154.76 & 149.21 & 240.00 & 383.54 & 41.36 & 18.58 & 31.64 \\
\hline 1890 & 227.05 & 151.21 & 233.00 & 303.90 & 42.89 & 18.52 & 32.44 \\
\hline 1891 & 145.64 & 143.71 & 236.51 & 333.13 & 43.68 & 23.92 & 38.19 \\
\hline 1892 & 164.33 & 152.37 & 195.46 & 273.76 & 39.38 & 21.20 & 31.67 \\
\hline 1893 & 278.67 & 155.10 & 199.69 & 290.30 & 43.18 & 22.23 & 27.06 \\
\hline 1894 & 257.23 & 133.89 & 195.93 & 270.37 & 38.54 & 19.28 & 20.62 \\
\hline 1895 & 176.74 & 113.52 & 244.95 & 293.12 & 34.20 & 19.19 & 23.64 \\
\hline 1896 & 237.19 & 107.26 & 224.30 & 290.05 & 31.97 & 22.96 & 31.59 \\
\hline 1897 & 182.86 & 104.58 & 234.25 & 284.36 & 29.81 & 16.49 & 30.40 \\
\hline 1898 & 232.47 & 144.74 & 301.35 & 256.03 & 32.46 & 16.98 & 39.18 \\
\hline 1899 & 154.58 & 109.04 & 248.72 & 325.97 & 34.93 & 16.47 & 26.91 \\
\hline 1900 & 130.78 & 74.26 & 319.02 & 329.69 & 46.53 & 20.08 & 28.14 \\
\hline 1901 & 128.13 & 131.66 & 251.28 & 241.14 & 49.09 & 22.07 & 29.03 \\
\hline 1902 & 163.92 & 146.04 & 235.92 & 233.06 & 52.52 & 23.98 & 30.39 \\
\hline
\end{tabular}


Table A2.1: (Continued)

\begin{tabular}{|l|c|c|c|c|c|c|c|}
\hline & Beef & Mutton & Hides & Wool & Linseed & Maize & Wheat \\
\hline 1903 & 154.87 & 158.92 & 271.28 & 265.70 & 39.48 & 21.67 & 29.44 \\
\hline 1904 & 123.16 & 152.50 & 256.46 & 301.50 & 31.58 & 20.53 & 31.36 \\
\hline 1905 & 121.07 & 188.44 & 276.37 & 359.13 & 38.09 & 23.48 & 32.04 \\
\hline 1906 & 122.52 & 148.17 & 307.27 & 402.58 & 43.79 & 21.65 & 31.40 \\
\hline 1907 & 138.09 & 180.89 & 325.43 & 429.55 & 43.70 & 26.09 & 37.22 \\
\hline 1908 & 145.01 & 139.09 & 286.61 & 358.79 & 43.92 & 27.57 & 37.92 \\
\hline 1909 & 134.75 & 119.17 & 352.40 & 399.23 & 45.00 & 27.75 & 42.73 \\
\hline 1910 & 140.45 & 177.64 & 353.56 & 383.37 & 81.10 & 23.89 & 37.61 \\
\hline 1911 & 131.17 & 144.14 & 358.04 & 341.72 & 74.46 & 24.16 & 35.66 \\
\hline 1912 & 147.54 & 236.03 & 407.63 & 373.77 & 63.60 & 26.15 & 35.95 \\
\hline 1913 & 156.27 & 168.41 & 457.21 & 398.55 & 44.77 & 25.91 & 36.63 \\
\hline
\end{tabular}

Source: see Appendix 6.

and, when the data are not available for the whole period, we complete the series by splicing our import unit values with the evolution reported in Sauerbeck's prices.

We plot and compare Saurebeck's prices and the import unit value proposed as international prices in this research (T\&W's prices) to illustrate the differences. The similarities between crop prices and hide prices, on the one hand, and the huge divergence between cattle prices, on the other hand, throw light on the differences in terms of quality and the impact of technological changes by type of commodity. In those commodities where the quality is relatively homogenous between varieties (cereals) or they are easily gathered (cereals, hides, wool), the price convergence is a more predictable process. However, in the case of perishable commodities, such as the different types of meat, and with notorious differences in terms of quality, the price differentials can be longer-lasting.

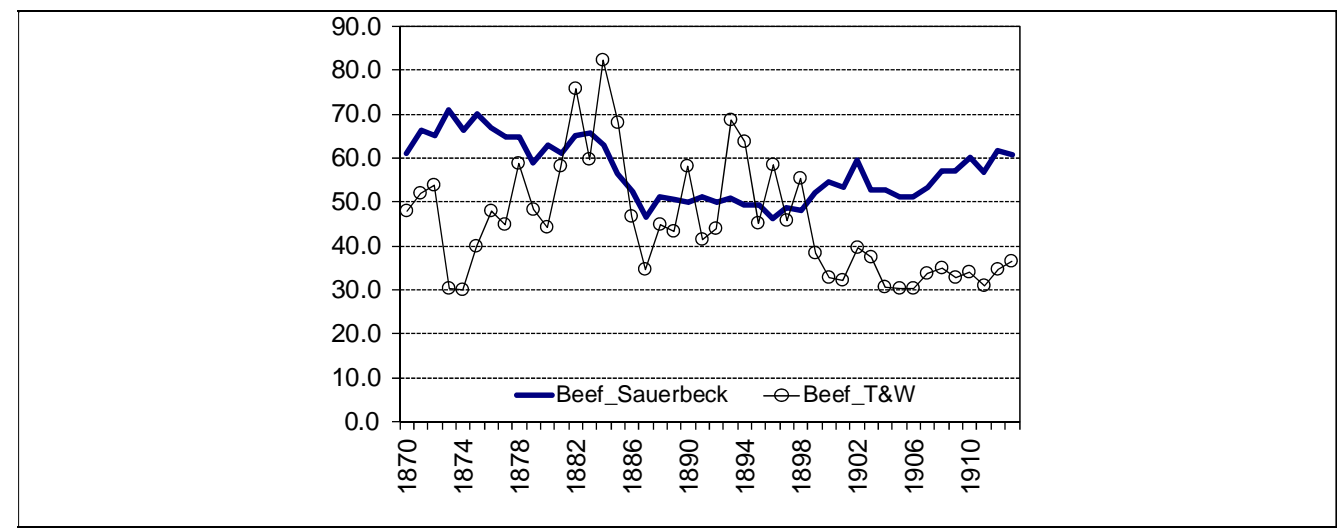

Figure A2.1 Beef prices, pounds by tonne c.if. 


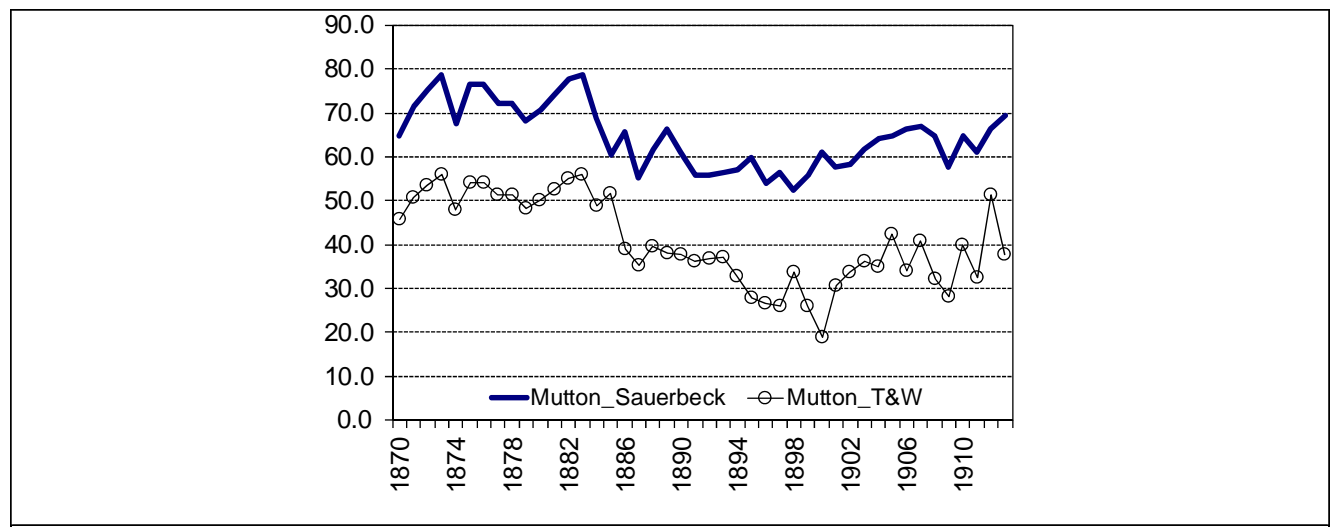

Figure A2.2 Mutton prices, pounds by tonne c.if.

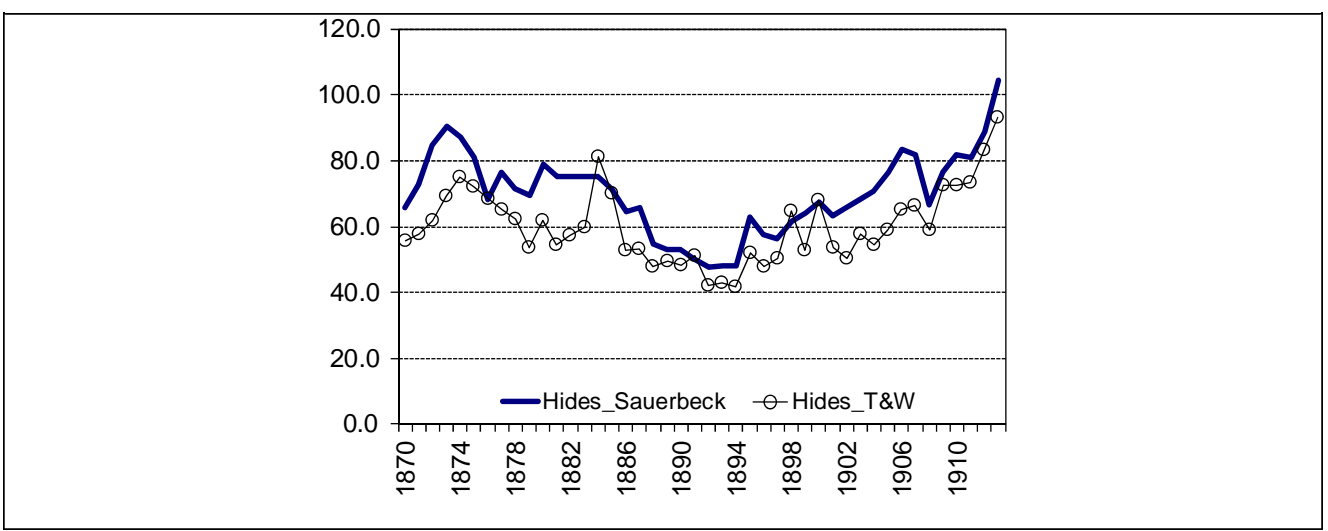

Figure A2.3 Hides prices, pounds by tonne c.i.f.

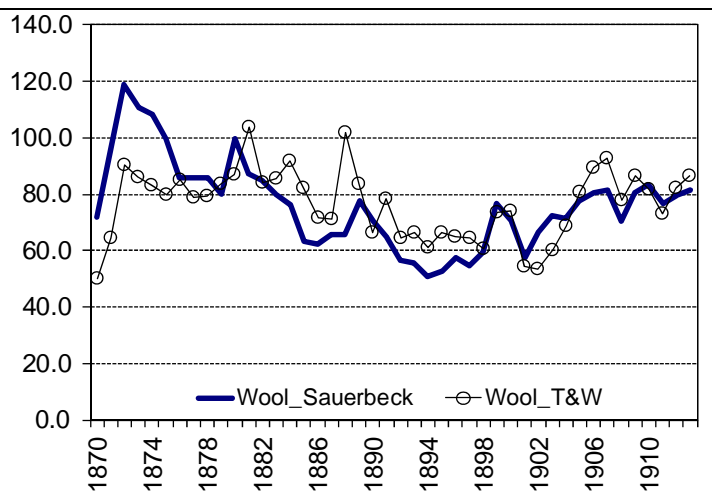

Figure A2.4 Wool prices, pounds by tonne c.iff. 


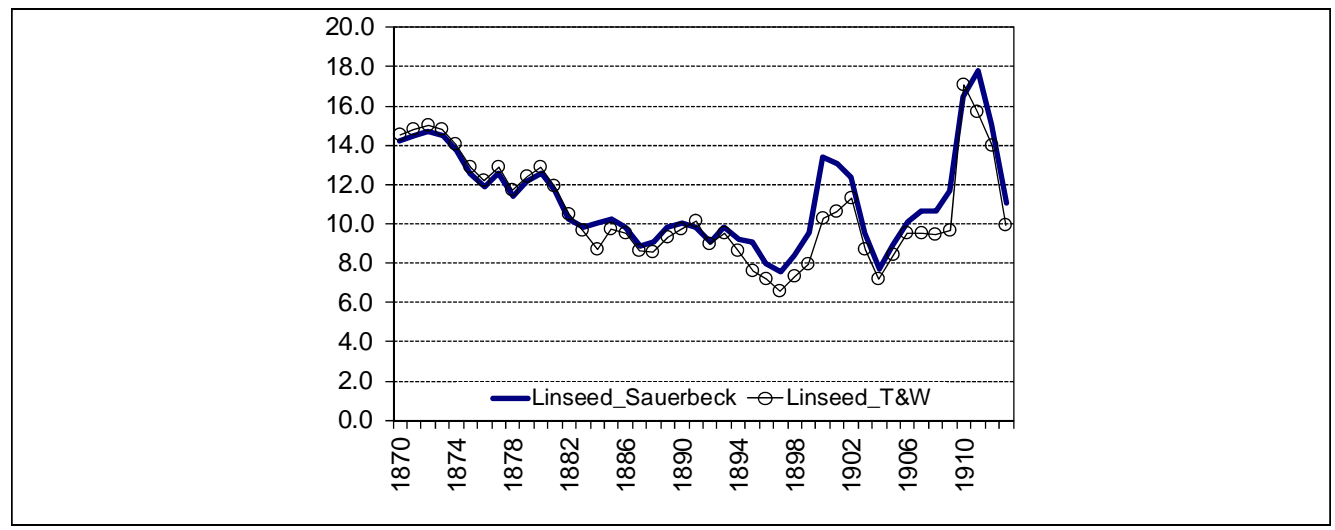

Figure A2.5 Linseed prices, pounds by tonne c.if.

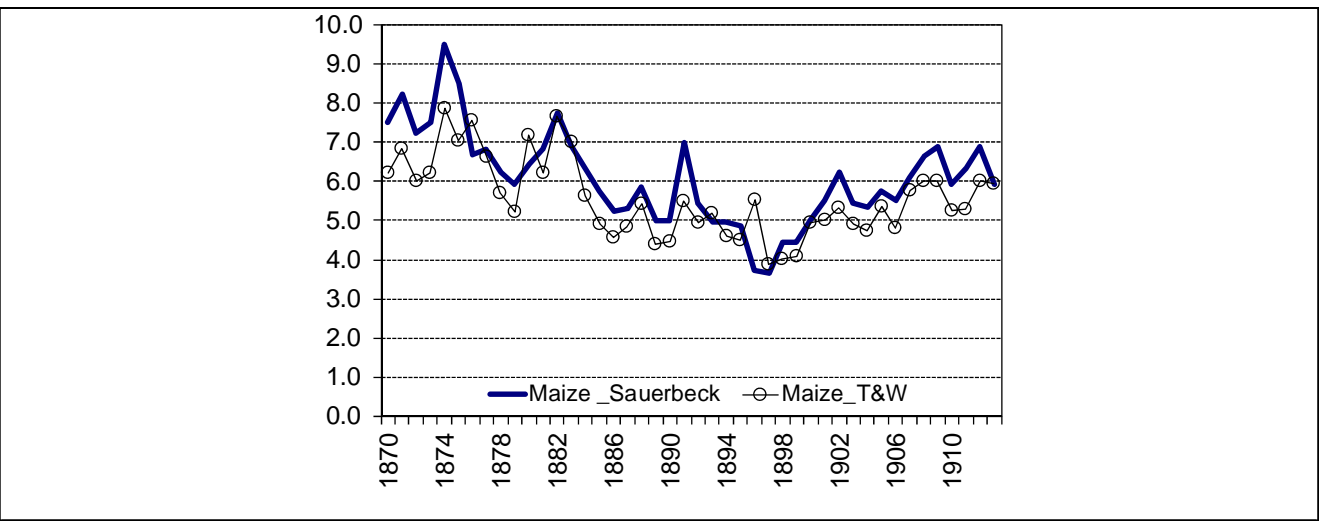

Figure A2.6 Maize prices, pounds by tonne c.iff.

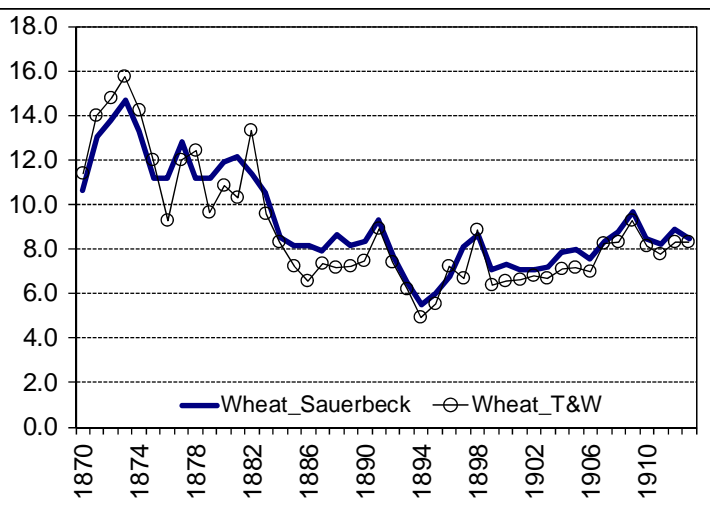

Figure A2.7 Wheat prices, pounds by tonne c.iff. 
Finally, international prices are declared c.i.f. import prices in UK records. We get f.o.b. prices free of tax at the Argentine border according to export tax and freight factor data offered in Figure 6 and Table A.3.1, respectively.

We define the price accuracy index (PAI) of country $i$ as:

$$
P A I_{i}=\sum_{j=1}^{N} \frac{P_{i j} * Q_{i j}}{P_{m j} * Q_{i j}}
$$

Where,

$P A I$ is the ratio between the volume of the good $j$ valued at the border of country $i$ (f.o.b. value of commodity exports) and the volume of the same products valued with the corresponding prices in the international markets discounting freight and insurance costs. Both prices are expressed in pounds. The commodities considered are: beef, mutton, hides, wool, wheat, maize and linseed and they represented, according to official data, 82 per cent of total exports of the period. ${ }^{2}$

$Q_{i j}$ is the volume of good $j$ according to the trade statistics of the country $i$.

$P_{i j}$ is the price of good $j$ according to the trade statistics of the country $i$ (expressed in pounds).

$P_{m j}$ is the international price of good $j$ (expressed in pounds).

$Q_{i j}$ and (implicitly) $P_{i j}$ were derived from official statistics - Estadistica del Comercio Exterior y de la Navegación de la República Argentina (1882-1892) and Anuario del Departamento Nacional de Estadística (1893-1913), but we require some criteria to homogenize retrospective series and we take as reference Latzina (1905, 180-228), and Tornquist (1919, 167-172). We confirm these data with Vazquez Presedo (1971) for values and Ferreres (2005) for quantities.

$P_{m j}$ is export tax and freight adjusted to get f.o.b. prices free of tax in Argentine border. It was derived from the unit value of the UK imports quantities and values from Argentina which are taken from several years of the Annual Statement of the Trade (1874, 1878, 1892, 1896, 1900, 1904, 1908, 1912, and 1915). Information is not available for some commodities for the whole period and we complete the series with the movement in Sauerbeck's prices: beef (1870-1874); mutton (1870-1882); linseed (1870-1881); maize (1870-1874); and wheat (18701874). 


\section{APPENDIX 3: COMMODITIES FREIGHT RATES AND FREIGHT FACTOR}

We estimated freight rates + insurance ratio on commodities c.i.f. prices for the main export commodities of Argentine exports used in our price index in order to convert c.i.f. prices in London to f.o.b. prices at the Argentine border. Freight rates evidence on commodities' transatlantic shipping is scarce so we made diverse estimation assumptions. The commodities freight rates estimated refer to the same products used in the estimation of our price index in Appendix 4: maize, wheat, wool, linseed, mutton, beef and hides. For maize we used annual grain freight rates from Buenos Aires to Rotterdam 1888-1913; for wheat the annual wheat freight rate from Buenos Aires to London 1887-1913; for wool the annual freight rates of wool Melbourne-London freight rates adjusted by the ratio of Buenos Aires/Melbourne wheat differential; for linseed the same as for wheat; for mutton, frozen meat, mutton \& beef $=0.375$ pence per $1 b$ in Argentina in 1910 and according to the evolution of the Wellington-London mutton 1883-1899 freight rate, we interpolated the series from 1899 to match the 1910 benchmark; for beef, the beef freight rate from Buenos Aires to London (see Vazquez Presedo 1979,189) which, in 1883, was: 2.5 pence per $1 \mathrm{~b}$; 1910: Chilled Beef $=0.6875$ pence per $1 \mathrm{lb}$, and frozen meat, mutton $\&$ beef $=0.375$ pence per $1 \mathrm{~b}$. The beef freight rate from 1883 to 1910 was estimated according to the evolution of the Wellington-London mutton 1883-1899. Taking into consideration the rapid refrigeration technological advances developed from the late 1890s, we interpolated the series from 1899 to match the 1910 benchmark. Finally, for hides we know the punctual freight rate from Buenos Aires-Montevideo to London in $1872=225$ pence per ton and we moved onwards according to the Buenos Aires to Rotterdam grain freight index. From the 1880s backwards we used the East American Grain Index offered in Mohamed-Williamson (2004, 182: Table 2). The freight rates mentioned, if not specified, came from Angier (1920) (see Appendix 6).

For insurance we assume a fixed 2 per cent insurance in 1900 moved backwards with the respective shipping freight rates. A 2 per cent insurance factor in 1900 based on Simon (1960, p.659). Other sources also appear to agree that 2 per cent seems a reasonable long-term equilibrium premium for most of the commodities. Moreover, insurance risk premium is also very sensitive to exogenous war and maritime blockades also increase the risk involved in shipping (as shown by the freight rates) and to endogenous decrease of risk incorporated by technological improvements as that shown by refrigeration technology at the turn of the 20th century or that shown in shipping textiles packaging on mid-19th century transatlantic routes. ${ }^{3}$

In the Table A3.1: Transatlantic freight rates of main Argentine export commodities, we offer our estimates of freight rates. The seven Argentine export commodities freight ratios were used in Appendix 3 to transform c.i.f. prices in f.o.b. prices for the respective commodities prices and in the estimation of our Argentine export price index. 
Table A3.1: Transatlantic freight rates of main Argentine export commodities

\begin{tabular}{|c|c|c|c|c|c|c|c|}
\hline & $\begin{array}{c}\text { Beef } £ \\
\text { per ton }\end{array}$ & $\begin{array}{c}\text { Mutton } £ \\
\text { per ton }\end{array}$ & $\begin{array}{l}\text { Hides } £ \\
\text { per ton }\end{array}$ & $\begin{array}{l}\text { Wool } £ \\
\text { per ton }\end{array}$ & $\begin{array}{l}\text { Linseed } £ \\
\text { per ton }\end{array}$ & $\begin{array}{l}\text { Maize } £ \\
\text { per ton }\end{array}$ & $\begin{array}{l}\text { Wheat } £ \\
\text { per ton }\end{array}$ \\
\hline 1870 & 23.81 & 12.99 & 0.74 & 6.75 & 1.01 & 0.91 & 1.01 \\
\hline 1871 & 28.81 & 15.71 & 0.89 & 8.17 & 1.22 & 1.11 & 1.22 \\
\hline 1872 & 30.35 & 16.55 & 0.94 & 8.61 & 1.28 & 1.16 & 1.28 \\
\hline 1873 & 32.41 & 17.68 & 1.00 & 9.19 & 1.37 & 1.24 & 1.37 \\
\hline 1874 & 29.32 & 15.99 & 0.91 & 8.32 & 1.24 & 1.13 & 1.24 \\
\hline 1875 & 24.69 & 13.47 & 0.76 & 7.00 & 1.04 & 0.95 & 1.04 \\
\hline 1876 & 24.69 & 13.47 & 0.76 & 7.00 & 1.04 & 0.95 & 1.04 \\
\hline 1877 & 28.29 & 15.43 & 0.87 & 8.02 & 1.20 & 1.09 & 1.20 \\
\hline 1878 & 24.69 & 13.47 & 0.76 & 7.00 & 1.04 & 0.95 & 1.04 \\
\hline 1879 & 24.69 & 13.47 & 0.76 & 7.00 & 1.04 & 0.95 & 1.04 \\
\hline 1880 & 26.23 & 14.31 & 0.81 & 7.44 & 1.11 & 1.01 & 1.11 \\
\hline 1881 & 26.75 & 14.59 & 0.83 & 7.59 & 1.13 & 1.03 & 1.13 \\
\hline 1882 & 25.00 & 13.64 & 0.77 & 7.09 & 1.06 & 0.96 & 1.06 \\
\hline 1883 & 23.15 & 12.63 & 0.72 & 6.56 & 0.98 & 0.89 & 0.98 \\
\hline 1884 & 23.15 & 12.63 & 0.58 & 5.34 & 0.80 & 0.72 & 0.80 \\
\hline 1885 & 21.12 & 11.52 & 0.56 & 5.11 & 0.76 & 0.69 & 0.76 \\
\hline 1886 & 17.36 & 9.47 & 0.56 & 5.11 & 0.76 & 0.69 & 0.76 \\
\hline 1887 & 18.81 & 10.26 & 0.54 & 4.96 & 0.90 & 0.67 & 0.90 \\
\hline 1888 & 15.91 & 8.68 & 0.59 & 5.40 & 0.87 & 0.73 & 0.87 \\
\hline 1889 & 15.91 & 8.68 & 0.56 & 5.11 & 1.00 & 0.75 & 1.00 \\
\hline 1890 & 14.47 & 7.89 & 0.56 & 5.18 & 1.08 & 0.87 & 1.08 \\
\hline 1891 & 14.47 & 7.89 & 0.64 & 7.33 & 1.33 & 0.85 & 1.33 \\
\hline 1892 & 11.57 & 6.31 & 0.52 & 6.46 & 1.10 & 0.78 & 1.10 \\
\hline 1893 & 11.57 & 6.31 & 0.44 & 4.60 & 0.83 & 0.73 & 0.83 \\
\hline 1894 & 11.57 & 6.31 & 0.37 & 3.84 & 0.95 & 0.84 & 0.95 \\
\hline 1895 & 9.89 & 5.39 & 0.41 & 3.94 & 0.90 & 0.74 & 0.90 \\
\hline 1896 & 10.13 & 5.52 & 0.46 & 3.88 & 0.84 & 0.68 & 0.84 \\
\hline 1897 & 8.68 & 4.73 & 0.55 & 3.90 & 0.64 & 0.56 & 0.64 \\
\hline 1898 & 7.23 & 3.95 & 0.59 & 7.09 & 0.92 & 0.70 & 0.92 \\
\hline 1899 & 7.23 & 3.95 & 0.48 & 5.23 & 1.16 & 0.98 & 1.16 \\
\hline 1900 & 7.15 & 3.90 & 0.50 & 4.55 & 1.08 & 1.06 & 1.08 \\
\hline 1901 & 7.07 & 3.86 & 0.48 & 4.10 & 0.86 & 0.65 & 0.86 \\
\hline 1902 & 6.99 & 3.81 & 0.48 & 5.99 & 0.68 & 0.58 & 0.68 \\
\hline
\end{tabular}


Table A3.1: (Continued)

\begin{tabular}{|c|c|c|c|c|c|c|c|}
\hline & $\begin{array}{c}\text { Beef } £ \\
\text { per ton }\end{array}$ & $\begin{array}{c}\text { Mutton } £ \\
\text { per ton }\end{array}$ & $\begin{array}{c}\text { Hides } £ \\
\text { per ton }\end{array}$ & $\begin{array}{c}\text { Wool } £ \\
\text { per ton }\end{array}$ & $\begin{array}{c}\text { Linseed } £ \\
\text { per ton }\end{array}$ & $\begin{array}{c}\text { Maize } £ \\
\text { per ton }\end{array}$ & $\begin{array}{c}\text { Wheat } £ \\
\text { per ton }\end{array}$ \\
\hline 1903 & 6.91 & 3.77 & 0.49 & 5.37 & 0.79 & 0.65 & 0.79 \\
\hline 1904 & 6.83 & 3.72 & 0.53 & 5.61 & 0.88 & 0.74 & 0.88 \\
\hline 1905 & 6.75 & 3.68 & 0.54 & 4.93 & 0.72 & 0.70 & 0.72 \\
\hline 1906 & 6.67 & 3.64 & 0.52 & 4.25 & 0.67 & 0.49 & 0.67 \\
\hline 1907 & 6.59 & 3.60 & 0.57 & 4.79 & 0.72 & 0.52 & 0.72 \\
\hline 1908 & 6.52 & 3.55 & 0.60 & 4.55 & 0.59 & 0.49 & 0.59 \\
\hline 1909 & 6.44 & 3.51 & 0.66 & 4.62 & 0.56 & 0.45 & 0.56 \\
\hline 1910 & 6.37 & 3.47 & 0.58 & 3.66 & 0.51 & 0.48 & 0.51 \\
\hline 1911 & 4.95 & 2.70 & 0.56 & 3.56 & 0.56 & 0.49 & 0.56 \\
\hline 1912 & 5.38 & 2.93 & 0.60 & 5.91 & 1.13 & 0.90 & 1.13 \\
\hline 1913 & 5.15 & 2.81 & 0.58 & 4.98 & 0.96 & 0.76 & 0.96 \\
\hline
\end{tabular}

Source: see Sources and References.

\section{APPENDIX 4: EXPORT PRICE INDEX}

We created an indicator to represent the movement of export prices at the border of the exporter country; i.e. we propose an index of free on board (f.o.b.) prices.

Our reference figure is the import unit value derived from the values and quantities of commodities imported by the UK from Argentina recorded as declared values in several volumes of the Annual Statement of the Trade of the United Kingdom (see discussion on quality goods of declared values in Appendix 2 ). We converted all figures to pounds sterling per ton from different price measures and specific types of the corresponding commodities. These figures represent c.i.f. prices, which were adjusted for export tax and freight to get f.o.b. prices free of tax at the Argentine border according to export tax and freight factor data offered in Figure 6 and Table A3.1.

The trade structure of Argentina changed significantly in this period and we considered it is convenient to elaborate an index number able to incorporate these changes in the calculations. Therefore we propose a Paasche Index Number and

3 The high risk for shipping frozen meat in the 1890s showed insurance per centages around $4 \%$ and $5 \%$ but rapid technological improvements in refrigeration technology changed this figure to $2 \%$ for beef at the turn of the century ("El problema del seguro tuvo también su evolución favorable. Tratandose de un riesgo nuevo, el premio era altísimo al comienzo entre $4 \%$ y $5 \%$ del valor transportado, que bajó al 2 con la entrada del nuevo siglo", Vazquez Presedo (1973), 89. See Figure 5 p.19 in Llorca-Jaña (2011) on the reduction of insurance from $3.5 \%$ to $2 \%$ in transatlantic British cotton exports in the 1850s because of technological improvements in shipping packaging. 
use exported quantities, year by year, to weight the respective prices corrected by our estimated freight factors. Prices were previously converted to pesos oro at a fixed rate of 5 pesos oro per pound (the implicit exchange rate used in the Annual Statement of the Trade surveys). Our formula is the following:

$$
X P I_{i, t, 1899-1901}=\frac{\sum_{j=1}^{N} P_{j, t} * Q_{j, t}}{\sum_{j=1}^{N} P_{j, 1899-1901} * Q_{j, t}}
$$

Where,

$X P I_{i, t, 1899-1901}$ is the Export Price Index of country $i$ (Argentina in our case) in the period $t$ considering the 1899-1901 average as the base period.

$P_{j, t}$ is the international price of commodity $j$ in period $t$.

$Q_{j, t}$ : is the volume exported of commodity $j$ (according to official Argentine data) in the period $t$.

We compare our XPI with the export price index standard in the literature derived from Blatman et al. (2004) and Williamson $(2000,2002)$ based on Ford (1955) (henceforth BHW). This BHW index $(1900=100)$ is a chained Laspeyres index that includes the Sauerbeck six commodities prices -hides/skins, linseed, maize, meat, wheat and wool (Merino). They are valued c.i.f. on the London market and cover the whole period. They use four weight sets (average participation by exported commodity): 1880-1884, 1898-1902, 1920-1924, and 1934-1938. They construct four series, one per period of weighting, corresponding to: $1860-1894,1885-1917,1908-1934$ and 1925-1950. These series have ten overlapping years and the connection between them consists of splicing pairs of series considering 90 per cent of the first one and 10 per cent of the second, 80 per cent of the first one, 20 per cent of the second and so on, year by year, until 100 per cent of the series is used with most recent weights. Trends are similar.

Argentina's export prices experienced a decreasing trajectory until the mid1890s and, from then, prices recovered significantly until the First World War. In accordance with our indicator, this recovery meant achieving the levels previous to the First Globalization boom, although this was not the case for the BHW index. In general, our indicator shows a more moderate evolution, especially before 1885 , with a less pronounced decrease and a slower increase. As a consequence of this more stable evolution, ${ }^{4}$ the $\mathrm{T} \& \mathrm{~W}$ indicator resulted 1.6 per cent higher than the BHW index throughout the period (average) and 5.6 per cent from 1880 to 1913.

4 The standard deviation of the BHW index exceeds that of the T\&W index by 60 per cent. 


\section{APPENDIX 5: NEW SERIES}

Table A5.1: Export of commodities: official and corrected data in current prices, corrected data in constant prices (pesos oro) and Export Price Index, Total, Cattle and Crops (1899-1901 = 100)

\begin{tabular}{|c|c|c|c|c|c|c|}
\hline & \multicolumn{3}{|c|}{ Pesos oro } & \multicolumn{3}{|c|}{ Export Price Index } \\
\hline & $\begin{array}{l}\text { Official (current } \\
\text { prices) }\end{array}$ & $\begin{array}{c}\text { Corrected } \\
\text { (current prices) }\end{array}$ & $\begin{array}{l}\text { Corrected (constant } \\
\text { prices, 1899-1901) }\end{array}$ & Total & Cattle & Crops \\
\hline 1870 & $30,326,400$ & $42,604,991$ & $45,155,442$ & 94.4 & 94.4 & - \\
\hline 1871 & $27,092,000$ & $38,061,043$ & $36,449,936$ & 104.4 & 104.4 & - \\
\hline 1872 & $47,424,000$ & $66,625,088$ & $57,940,857$ & 115.0 & 115.0 & - \\
\hline 1873 & $47,559,200$ & $66,815,028$ & $54,776,554$ & 122.0 & 122.0 & 147.7 \\
\hline 1874 & $44,688,800$ & $62,782,457$ & $52,968,641$ & 118.5 & 118.4 & 164.5 \\
\hline 1875 & $52,187,200$ & $73,316,819$ & $62,746,089$ & 116.8 & 116.8 & 167.7 \\
\hline 1876 & $48,256,000$ & $68,108,832$ & $60,060,688$ & 113.4 & 113.2 & 156.8 \\
\hline 1877 & $44,917,600$ & $64,196,498$ & $56,641,308$ & 113.3 & 113.2 & 145.7 \\
\hline 1878 & $37,648,000$ & $59,192,472$ & $53,681,484$ & 110.3 & 110.0 & 135.8 \\
\hline 1879 & $49,524,800$ & $61,223,853$ & $53,816,702$ & 113.8 & 112.5 & 154.1 \\
\hline 1880 & $58,572,800$ & $58,992,176$ & $48,822,361$ & 120.8 & 120.4 & 148.2 \\
\hline 1881 & $58,136,000$ & $68,621,590$ & $55,250,998$ & 124.2 & 123.9 & 140.9 \\
\hline 1882 & $60,590,400$ & $71,201,871$ & $56,544,467$ & 125.9 & 125.0 & 138.8 \\
\hline 1883 & $61,453,600$ & $72,886,433$ & $57,799,629$ & 126.1 & 125.1 & 141.7 \\
\hline 1884 & $68,255,200$ & $90,323,270$ & $71,455,856$ & 126.4 & 126.7 & 124.2 \\
\hline 1885 & $84,167,200$ & $92,168,181$ & $75,686,176$ & 121.8 & 124.0 & 108.4 \\
\hline 1886 & $70,075,200$ & $80,947,535$ & $73,280,062$ & 110.5 & 111.2 & 104.5 \\
\hline 1887 & $84,708,000$ & $75,890,921$ & $68,311,259$ & 111.1 & 112.6 & 106.5 \\
\hline 1888 & $100,453,600$ & $103,715,480$ & $88,928,265$ & 116.6 & 118.1 & 107.8 \\
\hline 1889 & $123,000,000$ & $110,049,859$ & $95,473,907$ & 115.3 & 117.1 & 102.9 \\
\hline 1890 & $101,160,800$ & $104,308,940$ & $95,815,856$ & 108.9 & 108.3 & 110.4 \\
\hline 1891 & $103,563,200$ & $111,868,643$ & $108,171,922$ & 103.4 & 100.3 & 119.3 \\
\hline 1892 & $113,755,200$ & $107,155,926$ & $103,773,917$ & 103.3 & 99.8 & 113.7 \\
\hline 1893 & $94,411,200$ & $125,134,302$ & $131,796,204$ & 94.9 & 95.0 & 94.8 \\
\hline 1894 & $102,034,400$ & $132,129,587$ & $141,125,432$ & 93.6 & 99.1 & 85.6 \\
\hline 1895 & $120,473,600$ & $166,795,675$ & $172,484,515$ & 96.7 & 99.7 & 92.0 \\
\hline 1896 & $117,197,600$ & $183,373,395$ & $187,760,612$ & 97.7 & 99.0 & 95.7 \\
\hline 1897 & $101,514,400$ & $131,150,042$ & $135,464,990$ & 96.8 & 98.1 & 90.4 \\
\hline 1898 & $134,284,800$ & $161,727,043$ & $163,872,560$ & 98.7 & 99.4 & 97.0 \\
\hline
\end{tabular}


Table A5.1: (Continued)

\begin{tabular}{|c|c|c|c|c|c|c|}
\hline & \multicolumn{5}{|c|}{ Pesos oro } & \multicolumn{2}{c|}{ Export Price Index } \\
\hline & $\begin{array}{c}\text { Official (current } \\
\text { prices) }\end{array}$ & $\begin{array}{c}\text { Corrected } \\
\text { (current prices) }\end{array}$ & $\begin{array}{c}\text { Corrected (constant } \\
\text { prices, 1899-1901) }\end{array}$ & Total & Cattle & Crops \\
\hline 1899 & $185,546,400$ & $200,804,970$ & $194,160,878$ & 103.4 & 103.4 & 103.4 \\
\hline 1900 & $155,335,800$ & $165,296,452$ & $165,296,452$ & 100.0 & 100.0 & 100.0 \\
\hline 1901 & $167,350,000$ & $182,970,083$ & $183,557,539$ & 99.7 & 93.7 & 109.4 \\
\hline 1902 & $179,426,500$ & $184,759,006$ & $186,343,222$ & 99.1 & 92.5 & 110.4 \\
\hline 1903 & $220,193,400$ & $247,622,682$ & $241,403,161$ & 102.6 & 97.2 & 106.9 \\
\hline 1904 & $263,443,100$ & $279,796,021$ & $266,114,581$ & 105.1 & 106.8 & 104.1 \\
\hline 1905 & $321,689,600$ & $334,019,253$ & $305,009,260$ & 109.5 & 112.1 & 107.7 \\
\hline 1906 & $291,963,800$ & $298,303,136$ & $251,818,853$ & 118.5 & 121.7 & 116.4 \\
\hline 1907 & $296,715,200$ & $334,686,839$ & $275,954,362$ & 121.3 & 122.4 & 120.5 \\
\hline 1908 & $365,021,700$ & $412,135,951$ & $323,721,663$ & 127.3 & 122.4 & 130.3 \\
\hline 1909 & $396,282,200$ & $413,747,541$ & $319,971,147$ & 129.3 & 119.8 & 136.4 \\
\hline 1910 & $388,471,200$ & $412,431,149$ & $319,996,373$ & 128.9 & 119.1 & 137.7 \\
\hline 1911 & $341,681,600$ & $346,216,350$ & $269,127,435$ & 128.6 & 122.3 & 137.9 \\
\hline 1912 & $501,144,800$ & $534,795,092$ & $417,113,162$ & 128.2 & 124.5 & 130.7 \\
\hline 1913 & $517,764,000$ & $549,771,267$ & $424,034,088$ & 129.7 & 128.8 & 130.1 \\
\hline
\end{tabular}




\section{APPENDIX 6: STATISTICAL SOURCES AND REFERENCES FOR THE CONSTRUCTION OF INDICATORS}

\begin{tabular}{|c|c|}
\hline Concept & Sources and comments \\
\hline Argentina & $\begin{array}{l}\text { Board of Trade. 1882. Statistical abstract for the Principal and other foreign } \\
\text { countries in each year from } 1871 \text { to 1880-81 (as far as can be stated). } \\
\text { Ninth number. } \\
\text { Departamento Nacional de Estadística } \\
1875-1879 \\
\text { Estadística de la República Argentina. Cuadro general del comercio exterior durante } \\
\text { el año de ... Formado sobre los documentos oficiales de aduanas. } \\
\text { 1880-1881 } \\
\text { Estadística del comercio y de la navegación interior y exterior de la República } \\
\text { Argentina correspondiente al año ... Publicación oficial. } \\
1882-1892 \\
\text { Estadística del comercio y de la navegación de la República Argentina } \\
\text { correspondiente al año ... Publicación oficial. } \\
1893-1913 \\
\text { Anuario del Departamento Nacional de Estadística correspondiente a... } \\
\text { Dirección General de Estadística de la Nación, República Argentina (1958): } \\
\text { Anuario del Comercio Exterior de la República Argentina, Buenos Aires. } \\
\text { Vázquez-Presedo, V. 1971. Estadísticas Históricas Argentinas. (Comparadas). } \\
\text { Primera Parte 1875-1914 Ediciones Macchi, Buenos Aires. }\end{array}$ \\
\hline United Kingdom & $\begin{array}{l}\text { Annual statement of the trade of the United Kingdom with foreign countries and } \\
\text { British possessions compared with the four preceding years. Compiled in the } \\
\text { Statistical Office of the Customs and Excise Department. Volume I. Several } \\
\text { volumes with the same title for the years 1874, 1878, 1892, 1896, 1900, 1904, } \\
\text { 1908, 1912, 1915. } \\
\text { Board of Trade (several years): Statistical Abstract for the United Kingdom, London. }\end{array}$ \\
\hline United States & $\begin{array}{l}\text { Bureau of Statistics (several years): Statistical Abstract of the United States, } \\
\text { Washington, Government Printing Office. }\end{array}$ \\
\hline France & $\begin{array}{l}\text { Tableau Général du Commerce de la France (several years): Annuarie Statistique } \\
\text { de la France, Paris. }\end{array}$ \\
\hline Germany & $\begin{array}{l}\text { Germany, Atatistisches Reichsamt (several years): Statistisches Jahrbuch für } \\
\text { Deutsche Reich, Berlin: R. Hobbing. }\end{array}$ \\
\hline Belgium & $\begin{array}{l}\text { Ministère de l'Intérieur et de l'Instruction Publique (several years): Statistique General } \\
\text { de la Belgique, Bruxelles - A Lesigne. }\end{array}$ \\
\hline Netherlands & $\begin{array}{l}\text { Jaarcijfers Voor Het Koninkrijk der Nederlanden (several years): Annuaire statistique } \\
\text { des Pays-Bas, Dutch Edition. }\end{array}$ \\
\hline Italy & $\begin{array}{l}\text { Federico, G., Natoli, S., Tattara, G., Vasta, M. 2012. // Commercio Estero Italiano } \\
\text { 1862-1950. Laterza. }\end{array}$ \\
\hline Spain & Instituto Nacional de Estadística (several years): Anuario Estadístico de España. \\
\hline
\end{tabular}




\begin{tabular}{|c|c|}
\hline Concept & and comments \\
\hline $\begin{array}{l}\text { ght and } \\
\text { rance }\end{array}$ & $\begin{array}{l}\text { Angier, E.A.V. 1920. Fifty Years of Freights 1869-1919, Fairplay, London. } \\
\text { Hanson, S. G. B. 1938. Argentine Meat and the British Market, Stanford: Stanford } \\
\text { University Press. } \\
\text { Mohammed, S.I. Shan and Williamson J.G. (2004) Freight rates and productivity } \\
\text { gains in British tramp shipping 1869-1950, Explorations in Economic History, } \\
\text { 41, no. 2: pp. 172-203. } \\
\text { Troubidge, J. and Raymond, J. (1912): A History of Meat Trade, London: Constable } \\
\text { and Company Ltd. } \\
\text { Vázquez-Presedo, V. 1979. El caso argentino: migración de factores, comercio } \\
\text { exterior y desarrollo 1875-1914. Buenos Aires: Eudeba. }\end{array}$ \\
\hline Exchange rates & $\begin{array}{l}\text { Annual statement of the trade of the United Kingdom with foreign countries and } \\
\text { British possessions compared with the four preceding years. Compiled in the } \\
\text { Statistical Office of the Customs and Excise Department. Volume I. Several } \\
\text { volumes with the same title for the years 1874, 1878, 1892, 1896, 1900, 1904, } \\
\text { 1908, 1912, 1915. } \\
\text { Dirección General de Estadística de la Nación, República Argentina. 1958. Anuario } \\
\text { del Comercio Exterior de la República Argentina, Buenos Aires. } \\
\text { Officer, L. 2001. "Dollar-Pound Exchange Rate From 1791". Measuring Worth, } \\
\text { 2010. URL: http://www.measuringworth.org/exchangepound/ }\end{array}$ \\
\hline
\end{tabular}

